\title{
REJESTR JEŃCÓW POLSKICH NA KRYMIE Z 1649 ROKU
}

\author{
Sławomir Augusiewicz \\ Uniwersytet Warmińsko-Mazurski w Olsztynie
}

\section{ABSTRACT \\ THE REGISTER OF THE POLISH CAPTIVES IN CRIMEA FROM THE YEAR 1649}

\begin{abstract}
The register of the Polish captives in Crimea taken during the Khmelnytsky Uprising comes from the letters of the Brandenburgian diplomats in Warsaw: Andreas Adersbach and Johann von Hoverbeck. Those letters are stored in GStAPK, located in Berlin-Dahlem. The register contains about 150 names, mainly cavalry unit companions and officers, taken captive during the Zhovti Vody campaign (21 $1^{\text {st }}$ April-16 $6^{\text {th }}$ May 1648) and battle of Korsun (26 $6^{\text {th }}$ May 1648). It describes the place of their hostage, sometimes mentioning the amount of ransom. The register was probably made in the first half of 1649, and could have been ordered by Jeremi Wiśniowiecki. It might have been used by the Ruthenian voivode to prepare a special list for the Crown's finance office, which contained the names of the captives and exact amount of ransom needed to be paid for them. This list is mentioned in the documents of the military commission which was held in March 1650.
\end{abstract}

Key words: Zhovti Vody 1648, Korsun 1648, the Crown army, Khmelnytsky Uprising, Crimea, Tartars, captives.

Słowa kluczowe: Żółte Wody 1648, Korsuń 1648, wojsko koronne, powstanie Bohdana Chmielnickiego, Krym, Tatarzy, jeńcy.

Brak zainteresowania historyków losami jeńców polskich na Krymie dostrzegł już przed siedemdziesięciu laty Bohdan Baranowski ${ }^{1}$, a jego konstatację powtórzył niedawno Mirosław Nagielski². Jak poważna to luka w badaniach nie tylko nad

${ }^{1}$ B. B a ra now s k i, Dzieje jasyru na Gródku karaimskim, „Myśl Karaimska” 1946-1947, R. XXIV, Seria Nowa, t. II, s. 40-41.

${ }^{2}$ M. Nagi ielski, Z dziejów jasyru polskiego w Bachczysaraju w połowie XVII w. Przyczynek do działalności dyplomaty i tlumacza języków orientalnych Romaszkiewicza w shu̇bie Rzeczypospolitej

Adresy do korespondencji: slawaug@wp.pl; slawomir.augusiewicz@uwm.edu.pl 
stosunkami polsko-tatarskimi, ale także nad historią wojenną i biografistyką wojskową okresu staropolskiego, uwidacznia podsumowanie naszej dotychczasowej wiedzy na temat rotmistrzów i towarzyszy chorągwianych, wziętych do niewoli w pierwszym miesiącu powstania Bohdana Chmielnickiego w 1648 roku, spośród których znamy - oprócz hetmanów koronnych Mikołaja Potockiego i Marcina Kalinowskiego - nazwiska: Jacka Szemberka, Mikołaja Bieganowskigo, Adama Hieronima Sieniawskigo, Jana Fryderyka Sapiehę, Jerzego Bałabana czy Jana Odrzywolskigo. O ile oczywiście nie jest możliwe ustalenie liczebności jasyru, o tyle może to dać wyobrażenie o skali zjawiska i podstawę do określenia szacunkowych danych przy podejmowaniu próby poszerzenia o dalsze nazwiska wykazu jeńców, który mógłby jednocześnie stanowić punkt wyjścia badań postulowanych przez wymienionych wyżej historyków. W rzeczywistości zmusza to, jak zauważył Nagielski, do podjęcia żmudnych i długotrwałych badań archiwalnych. Większość znanych, niektórych nawet kilkakrotnie publikowanych relacji do kampanii żółtowodzkiej (21 IV - 16 V 1648) i bitwy pod Korsuniem (26 V 1648) oraz pochodzących z tego okresu korespondencji ${ }^{3}$, sporządzanych wśród panującego chaosu na podstawie często niepewnych, a nawet sprzecznych informacji zawiera skąpe w tym zakresie dane. Nieco obszerniejsze wykazy zawierają jedynie sporządzone krótko po wydarzeniach relacje Jakuba Bełchackiego ${ }^{4}$ i zbiegłego z niewoli Pawła Kochana ${ }^{5}$ oraz Pamiętniki do panowania Zygmunta III, Władysława IV i Jana Kazimierza ${ }^{6}$.

W istocie nie źródła narracyjne, lecz rejestry osób, które przebywały w niewoli tatarskiej lub świeżo z niej powróciły, mogą się stać podstawowym materiałem do opracowania wykazu jeńców. „Regestr towarzystwa, których przywieźli do Chocynia swotrzemie [?] Tatarowie Tohajbeja"7, zawiera nazwiska 22 towarzyszy chorągwi rozbitych pod Korsuniem. 11 spośród nich wymienia „Komput generalny szacunków wszytkich towarzystwa w Jaziech w więzieniu", zawierający również specyfikację sum okupu. Pierwszy wykaz powstał zapewne w pierwszych

[w:] Polacy na poludniowej Ukrainie, red. T. C i e s i els s i, W. K u s zn i r, Odessa-Opole-Olsztyn 2006, s. 53, 63; M. N a g i elsk i, Sytuacja jeńców w początkowym okresie powstania Chmielnickiego w latach 1648-1652, „Przegląd Historyczny” 2014, t. CV, z. 4, s. 565.

3 Źródła te omówił W. Maje w sk i, Krytyczny przegląd źródeł do dziejów powstania Chmielnickiego w okresie początkowym (jesień 1657 - maj 1648), „Studia Źródłoznawcze” 1981, t. XXVI, s. 141-162.

${ }^{4}$ List Jakuba Betchackiego z obozu pod Czerkasami do niewiadomego o klęsce żóttowodzkiej [w:] T. Krząstek, W. Majewski, M. Nagi elski, I.S. S torożenko, Żótte Wody-1648, Warszawa 1999 , s. 90-92. Bełchacki wymienia nazwiska 10 towarzyszy chorągwianych, wziętych do niewoli zapewne podczas odwrotu tzw. grupy lądowej znad Żółtych Wód pod Kniażymi Bajrakami 16 V 1648.

${ }^{5}$ P. Kochan do NN, Bar 5 VI 1648. Документы об освободительной войне украинского народа 1648-1654 гг, Київ 1965, s. 38. Kochan wymienia nazwiska 12 osób, głównie oficerów wraz z sumami okupu.

${ }^{6}$ Zawierają informacje o ok. 25 jeńcach znad Żółtych Wód i spod Korsunia. Pamiętniki do panowania Zygmunta III, Władystawa IV i Jana Kazimierza, wyd. K.W. W ój ci cki, Warszawa 1846, t. I, s. $283,287$.

7 Джерела з історіі Національно-визвольної війни украӥнського народу 1648-1658 рр., t. I: (1648-1649 pp.), упор. Ю. М и ц и к, Київ 2012, t. I, s. 34-35, 412. Zob. M. N a g i e 1 s k i, Sytuacja jeńców..., s. 567.

${ }^{8}$ Archiwum Państwowe w Gdańsku (dalej: APGd), 300, R/Ee 32, s. 398-399, 466. 
dniach lipca 1648 roku, o wymienionym w nim ,panu Mysłowskim”, przybyłym do Kamieńca „Z więźniami [...], którzy tu wczoraj [6 lipca] późno przyjechali” wspomniał w relacji z tego właśnie okresu sędzia podolski Łukasz Miaskowski. Również szlachcianka Zuzanna Jarmolińska pisała z Kamieńca, że „barzo siła [jeńców] do Chocimia przywieziono na okup” ${ }^{10}$. „Komput generalny” może być wcześniejszy i dotyczyć jeńców, którzy „oszacowali się” i oczekiwali na uwolnienie po dostarczeniu okupu. Wymiany dokonywano zazwyczaj w Jassach, Chocimiu i Kamieńcu ${ }^{11}$. Poza tym, wobec ówczesnej sytuacji na Ukrainie, przez rządzoną przez przychylnego wówczas Rzeczypospolitej hospodara Bazylego Lupula Mołdawię prowadziła bezpieczniejsza droga dla powracających z niewoli tatarskiej. Już jesienią 1648 roku „Credens J.K.M., który był posłany od J.M.P. kanclerza [Jerzego Ossoilińskiego] za tymi więźniami, aby ich wieziono do Wołoch, co się już oszacowali”'2. Również przez Jassy wracał z Krymu rok później w towarzystwie kilku innych byłych jeńców Stanisław Zygmunt Druszkiewicz ${ }^{13}$. Z pewnością przyczyny tworzenia rejestrów były ściśle powiązane $\mathrm{z}$ procesem wykupu z niewoli, którego mechanizmy stanowią jednak odrębny problem, już podejmowany przez historyków, ale wydaje się że wciąż jeszcze niewystarczająco zbadany ${ }^{14}$.

Najobszerniejszy ze znanych dotchczas „Regestr niewolników z Krymu, 1649”15, został sporządzony w 1649 roku w związku ze wznowieniem, przerwanych zimą, starań strony polskiej o wykupienie jeńców. Zebrano w nim informacje o 61 osobach, podając nazwiska i miejsce ich przetrzymywania. Jak wskazują stosowane niekiedy w rejestrze zapisy w pierwszej osobie (,Stanisław Rusiecki, gdzie ja siedzę u Tatarzyna, którego zowią Tynitrylle we wsi Usskwie Tarcan”, „Andrzej Słepowroński, Stephan Chołchowski, oba siedziemy w Achmeci"'16), sami uwięzieni przekazywali dane anonimowemu autorowi spisu. Dobre rozeznanie miał Łukasz Miaskowski, któremu wiadomości dostarczali wracający z niewoli przez Kamieniec jeńcy, często ponadto przewożący listy z $\mathrm{Krymu}^{17}$. Sędzia podolski był poza tym - na polecenie

${ }^{9}$ Ł. Miaskowski do NN, Kamieniec 7 VII 1648. Джерела..., t. I, s. 87.

${ }^{10}$ Джерела..., t. I, s. 57.

11 „Jakoż to u mnie nie jest bez podziwienia, iż jakom z koronacyjej [Jana Kazimierza, 17 I 1649] przyjechał, żadnego przez ten wszystek czas, choć zima długo trzymała, ani do Jass, ani tu do Chocimia Tatarowie więźnia na okup nie przywieźli”. Ł. Miaskowski do NN, Kamieniec 23 IV 1649. Jakuba Michatowskiego, wojskiego lubelskiego a później kasztelana bieckiego księga pamiętnicza, wyd. A.Z. He lc el, Kraków 1864 (dalej: Michałowski), s. 389, cyt. za: B. B ar a n ow sk i, Dzieje jasyru..., s. 50.

${ }_{12}$ P. Daszkiewicz do K. Korcykiego, Kozłów [Gözlew] 21 XI 1648. Документы..., s. 196; NN do NN, bm [pocz. kwietnia 1648]. Джерела..., t. I, s. 81; D. Milew ski, Rywalizacja polsko-kozacka o Moldawię w dobie powstania Bohdana Chmielnickiego (1648-1653), Zabrze 2011, s. 81.

${ }^{13}$ S.Z. Druszkiew i c z, Pamiętniki 1648-1697, wyd. M. Wagner, Siedlce 2001, s. 89.

${ }_{14}$ Por. B. B aranowski, Dzieje jasyru..., s. 49-51; M. Wagn er, Wykup jeńców z niewoli tureckiej i tatarskiej w końcu XVII wieku, „Українська Орієнталістика”, Випуск 6, Київ 2012, s. 29-35; M. N a g i els k i, Z dziejów jasyru..., s. 53, tam szczegółowy wykaz literatury.

${ }_{15}$ Джерела..., t. I, s. 409-410 (dalej: „Regestr niewolników”).

16 „Regestr niewolników”. Джерела..., t. I, s. 409-410.

17 „Więźniów, których wieźć na okupy miano, zatrzymano [...], o czym od kilku z Krymu miałem listy”. Ł. Miaskowski do NN, Kamieniec po 16 VII 1648. Джерела..., t. I, s. 293. „Wczoraj też pan Pozański oswobodził w Chocimiu pana Piekarskiego od J.M. Pana krakowskiego [Mikołaja Potockiego] z listami posłanego [...] jest jeden do W.M. Pana". Ł. Miaskowski do K. Koniecpolskiego, 
wspierającego polskie starania o uwolnienie hetmanów Lupula - informowany o sytuacji na Krymie przez perkułaba chocimskiego Petryczejkę ${ }^{18}$, miał też swoich konfidentów w Jassach ${ }^{19}$. Ponadto już od lata 1648 roku na Krym docierali polscy wysłannicy, którzy mieli negocjować warunki uwolnienia hetmana Potockiego: Ormianin Romaszkiewicz, dyplomata i tłumacz w służbie polskiejej, starosta sokalski Zygmunt Denhoff w listopadzie 1648 roku $^{21}$ i Stanisław Mariusz Jaskólski w pierwszej połowie 1649 roku $^{22}$. Wiosną 1649 roku karmelita, ojciec Hilary „eliberować więźniów na Budziaki pojechał”23. Poza tym, jak kiedyś pisał Antoni Rolle: „najczęściej tłumacze Ormianie albo Grecy od dawna w kraju osiedli przyjmowali oni na siebie wszystkie troski «wywiedzenia się» o miejscu, w którym przebywa braniec, a potem wykupno jego i odstawienie pod strzechę ojczystą" ${ }^{24}$. Źródeł informacji do sporządzenia spisu mogło być więc wiele, stąd też mogły wynikać pomyłki, polegające choćby na zamieszczaniu w nim niektórych nazwisk dwukrotnie (np. wspomnianego wyżej Druszkiewicza).

woj. bełskiego, Kamieniec 26 VIII 1648. APGd, 300, R/Ee 32, s. 526. „Przynisł tu, dziś trzeci dzień, pan Jan Chojnacki z niewoli oswobodzony [...] od pana Stanisława Radziszewskiego [...] list z Zakopanki wsie z pod Białogrodu die 8 praesentis pisany". Ł. Miaskowski do NN [Kamieniec] 23 IV 1649. Michałowski, s. 388. O listach jeńców polskich przychodzących z Krymu do Kamieńca Podolskiego, m.in. od Mikołaja Bieganowskiego, pisał Marek Sobieski z obozu pod Czołhańskim Kamieniem 31 VIII 1648. Документы ..., s. 108. 3 lipca 1649 Miaskowski donosił swojemu bratu Wojciechowi o korespondencji Jana Fryderyka Sapiehy, która dotarła z Krymu do Kamieńca. Джерела..., t. I, s. 275. Poza tym znane są listy z niewoli Mikołaja Potockiego (M. Potocki do Ł. Miaskowskiego, z obozu tatarskiego 1 VI 1648. K. Szajn o ch a, Dwa lata dziejów naszych 1646. 1648. Opowiadanie i źródła, t. II: Polska w 1648, Lwów 1869 (dalej: Szajnocha), s. 328; M. Potocki do A.H. Sieniawskiego, Kaffa 7 IX 1648. Джерела..., t. I, s. 151-152; Jerzego Bałabana (J. Bałaban do A.H. Sieniawskiego, bmd, APGd, 300, R/ Ee 32, s. 454-455). Takich korespondencji mogło być wiele: „Wiele więźniów piszą [...] z Krymu i przyjaciele nasi mianowicie pan Lodochowski do J.M. Pani sędziny krzemienieckiej, matki swej z panem Brzuchowskim [Aleksandrem Brzuchańskim?] i z innemi", NN do J. Ossolińskiego, Mikulińce 22 XI [1648], APGd, 300, 29/133, k. 306.

${ }^{18}$ Ł. Miaskowski do J. Ossolińskiego, Kamieniec 4 VII 1648. Szajnocha, s. 359-361; D. Milew ski, op. cit., s. 80 .

${ }^{19}$ Ł. Miaskowski do W. Miaskowskiego, Kamieniec 3 VII 1649. Джерела..., t. I, s. 275.

${ }^{20}$ B. Baranowski, Ormianie w stużbie dyplomatycznej Rzeczypospolitej, „Myśl Karaimska” 1946, R. XXIII, Seria Nowa, t. 1, s. 130; M. Na gi elsk i, Z dziejów jasyru..., s. 59; M. N a g i elski, Romaszkiewicz (Romaszkiewic, Ramaszkiewicz, Ramaszkowicz) Jan badź Piotr (zm. po 1667) [w:] Polski Stownik Biograficzny (dalej: PSB), t. XXXI, Kraków 1988-1989, s. 620.

${ }^{21}$ P. Daszkiewicz do K. Korcykiego, Kozłów [Gözlew] 21 XI 1648. Документы ..., s. 196; D. M ilewski, op. cit., s. 81.

${ }^{22}$ Ł. Miaskowski do NN, Kamieniec 3 V 1649. Ojczyste spominki w pismach do dziejów dawnej Polski. Diaryusze, relacje, pamiętniki, t. II, wyd. A. Grabow sk i, Kraków 1845, s. 17-18; Michałowski, s. 72 (ten sam list z błędną datą 3 VII 1648; Jaskólski jeszcze 9 czerwca był w Barze, 16 czerwca w Winnicy, nie mógł więc w tym miesiącu prowadzić rokowań o wykupienie hetmana na Krymie. Джерела, t. I, s. 73; Michałowski, s. 38); NN do NN, bm po 18 VII 1649. Джерела..., t. I, s. 293.

${ }^{23}$ Ł. Miaskowski do NN [Kamieniec] 23 IV 1649. Michałowski, s. 388. Ojca Hilarego, karmelitę w Kamieńcu, „który wiele pomaga staraniem i porcyją swoją utrapionym więźniom”, wspomina „Instrukcja [...] posłom wojskowym w kole generalnym pod Lwowem na sejm walny warszawski”, 22 XI 1649, APG 300, 53/101, s. 41.

${ }^{24}$ A. Rolle, Zdrada kamieniecka [w:] Opowiadania historyczne, seria VII, Lwów 1891, s. 38. 
Ostatni ze znanych wykazów jeńców, którego geneza jest jednak odmienna od pozostałych, to załączony do instrukcji posłom wojskowym z koła generalnego pod Lwowem z 22 XI 1649 „Regestr kompaniej różny, którzy teraz świeżo z niewoli pogańskiej wyszli, a wzięci byli pod Korsuniem”25, zawierający 19 nazwisk. Zamieszczenie tej listy w instrukcji związane było zapewne $\mathrm{z}$ wysuwanymi przez wojsko żądaniami, aby żołnierzom pozostającym w niewoli „od Rzeczypospolitej na eliberacyją w sprawie, drugim do służby konferowana była kwota i tym, którzy do tego czasu w więzieniu zostawają, aby żołd w skarbie Rrzeczypospolitej szedł"26. Postulat ten ponawiano w styczniu 1650 i na obradach komisji wojskowej w Lublinie w marcu tego roku ${ }^{27}$. Ostatecznie przyznano 40 tys. zł na wykupienie hetmana polnego koronnego Marcina Kalinowskiego, oraz 86 tys. zł na „okup różnego towarzystwa, którzy po rozgromie korsuńskim ze wszytkiego wojska dotąd w niewoli tatarskiej zostają, a drudzy już powychodzili, wedle sepecyfikacyjej i regestru imion i przezwisk ręką J.M. Pana wojewody ruskiego [Jeremiego Wiśniowieckiego] podpisanego i do skarbu podanego, komputując na osobę każdego po zł. 170"28.

Można przypuszczać, że ów rejestr sporządzony przez Jeremiego Wiśniowieckiego był najobszerniejszą listą jeńców, niestety nie udało się go odnaleźć, być może się nie zachował. Niewykluczone jednak, że podstawę do jego opracowania stanowiły zarówno wymieniony już „Regestr niewolników”, jak i zamieszczony poniżej, nieznany dotąd „Regestr więźniów”. Obydwa mogły powstać niezależnie od siebie, ale w podobnym czasie, na co wskazują zbieżności w ich treści. „Regestr więźniów” jest znacznie obszerniejszy niż pozostałe, zawiera ok. 150 nazwisk, w większości rotmistrzów i towarzyszy, wziętych do niewoli tatarskiej podczas kampanii żółtowodzkiej (z tzw. grupy wodnej, uwięzionych po buncie Kozaków rejestrowych $4 \mathrm{~V} 1648$ i z chorągwi rozbitych podczas odwrotu grupy lądowej pod Kniażymi Bajrakami $16 \mathrm{~V}$ 1648) oraz podczas bitwy pod Korsuniem (26 V 1648) ${ }^{29}$. Wydaje się jednak, zważywszy na obecność w spisie niewymienionej z imienia Wasilkowskiej de domo Strzemeskiej, że uwzględnia również pewną liczbę cywilów wziętych w jasyr przez ordę. Dokument, prawdopodobnie oryginal, jest przechowywany w Geheimes Staatsarchiv Preussischer Kulturbesitz w Berlinie w zbiorze relacji dyplomatów brandenburskich w Warszawie: Johanna von Hoverbecka i Andreasa Adersbacha

${ }^{25}$ APG 300, 53/101, s. 44. Zob. M. N a gi els k i, Z dziejów jasyru..., s. 63.

26 ,Instrukcja [...] posłom wojskowym w kole generalnym pod Lwowem na sejm walny warszawski, die 22 Novebris1649". APG 300, 53/101, s. 37-44. Jednemu z wymienionych w rejestrze towarzyszy, Gromackiemu ,po sejmie blisko przeszłym [zakończonym ex senatus consulto [...] zapłaconych na takowyż okup 3000 [zł]”, ,Zapłata wojskom J.K.M. i Rzeczypospolitej na komisiej lubelskiej pro die quinta Marty Anni 1650, podług sejmu walnego warszawskiego w roku 1649 odprawionego złożona". Archiwum Główne Akt Dawnych w Warszawie, Akta Skarbowo-Wojskowe (dalej: AGAD ASW), dz. 86, nr 39, k. 44v (dalej: „Zapłata wojskom”). Zob. Ł. C zęś c i k, Sejm warszawski w 1649/1650 roku, Wrocław 1978, s. 91-94.

27 „Dezyderata od deputatów wojska”, Lublin 1 I 1650. Michałowski, s. 526; E. J a n a s, Konfederacja wojska koronnego $w$ latach 1661-1663, Lublin 1998, s. 18-19.

28 „Zapłata wojskom”, k. 44.

${ }^{29}$ W. Biernacki, Żótte Wody-Korsuń 1648, Warszawa 2004, s. 82-181; W. Majewski, Żótte Wody-1648 r. [w:] T. Krząstek, W. Majewski, M. Nagielski, I.S. Storożenko, op. cit., s. 23-33. 
z 1649 roku $^{30}$, w którym oprócz niego znajdują się kopie znanych z polskich zbiorów rękopisów i publikowanych źródeł do pierwszego okresu wojny polsko-kozackiej (z lat 1648-1629), między innymi: diariusz oblężenia Zbaraża ${ }^{31}$ (k. 78-79v), „Kondycyje od ludzi z Kudaku wychodzących podane”32 (k. 206-207), „Komput wojska kwarcianego z ordynacyjej Rzeczypospolitej [1649]"33 (k. 232-232v) oraz odpisy korespondencji: Jana Kazimierza, Bohdana Chmielnickiego, Adama Kisiela, Krzysztofa Przyjemskiego i innych.

Brakuje przesłanek umożliwiających zidentyfikowanie podpisanego pod „Regestrem więźniów” Osińskiego. Z dużym prawdopodobieństwem można natomiast ustalić, że spis został sporządzony wiosną, najpóźniej na początku czerwca 1649 roku, gdyż zawiera nazwiska czterech osób (Kalinowski, Gniewosz, Kaski, Borzewicki) z sześciu, które według relacji sędziego podolskiego Łukasza Miaskowskiego, opuściły niewolę tatarską i dotarły do Kamieńca 3 lipca tegoż roku ${ }^{34}$. „Regestr więźniów” i częściowo z nim w tym fragmencie zbieżny „Regestr niewolników" lokalizuje ich w Jassach (tylko Kalinowski miał przebywać w Białogrodzie). Ponieważ obydwa spisy zawierają ponadto nazwisko Druszkiewicza, możemy tę grupę identyfikować $\mathrm{z}$ wymienionymi w relacji pamiętnikarza jeńcami (w tym z Gniewoszem i Borzewickim) wykupionymi wraz z nim w stolicy Mołdawii przez Bośniaka Michała Milicza ${ }^{35}$. „Od jednych w Jasiech w Wołoszech pobrał pieniądze, a drugich nas aż do Warszawy wywiózł na sejm [rozpoczęty 22 XI 1649]. Oddałem mu i ja wszystkie pieniądze"36. Pozostali przez Kamieniec, jak potwierdza Miaskowski, dotarli do obozu wojskowego pod Lwowem i zaciągali się ponownie pod chorągwie ${ }^{37}$, jak można wnosić ze wspomnianego wyżej „Regestru kompaniej”, który zawiera kilka nazwisk z obydwóch spisów jeńców, relacji Druszkiewicza i Miaskowskiego.

„Regestr więźniów” został sporządzony na dwóch kartach złożonych wzdłuż, na sześciu stronach z ośmiu utworzonych w ten sposób zapisano po jednej kolumnie nazwisk. Analiza treści oraz widoczna pierwotna paginacja wskazuje, że zmieniono kolejność stron dokumentu w układzie jednostki archiwalnej. W publikowanym tekście zachowano pierwotną kolejność nazwisk, podając jednak zarówno starą, jak i archiwalną paginację.

${ }^{30}$ Geheimes Staatsarchiv Preussischer Kulturbesitz Berlin-Dahlem, XX Hauptabteilung, Etats Ministerium 111h, nr 152, k. 181-183v.

${ }^{31}$ Dyaryusz krótszy oblężenie Zbaraża. Michałowski, s. 444-448; Zob. też Relacje wojenne z pierwszych lat walk polsko-kozackich powstania Chmielnickiego okresu „Ogniem i mieczem” (1648-1651), wyd. M. N a gi els k i, Warszawa 1999, s. 169-174.

32 Zob. Документыл..., s. 153-154.

33 Zob. Michałowski, s. 426-428.

34 Ł. Miaskowski do W. Miaskowskiego, Kamieniec 3 VII 1649. Джерела..., t. I, s. 275. Fragment listu z drobnymi zmianami (zamiast Borzewickiego jest porucznik księcia Koreckiego) opublikował Ambroży Grabowski. Zob. Ojczyste spominki..., t. II, s. 55.

35 S.Z. Druszkiewi c z, op. cit., s. 12-13, 88-89.

36 Ibidem, s. 89.

${ }^{37}$ M. Nagiels ki, Sytuacja jeńców..., s. 573. 
Edycję przygotowano według zasad Instrukcji wydawniczej dla źródeł historycznych od XVI do połowy XIX w. (red. K. Lepszy, Wrocław 1953). Zmodernizowano pisownię, w tym nazwisk i nazw miejscowych, pozostawiając oryginalną pisownię w przypadkach gdy nie była możliwa lub budziła wątpliwości ich identyfikacja, niekiedy pozostawiając jednak charakterystyczne dla źródła zniekształcenia. Usunięto większość wielkich liter, oprócz sygli, które zachowano, rozdzielając tylko poszczególne litery kropkami. Pozostałe skróty zostały rozwiązane, tylko w przypadku imion i nazwisk uzupełnienie zostało oznaczone nawiasem kwadratowym. Zachowano i ujednolicono skrót terminu odnoszącego się do pieniędzy (tal. - talarów).

W przypisach, o ile to było możliwe, podano identyfikację osób występujących w rejestrze. W przypadkach popularnych, często występujących w źródłach z tego okresu nazwisk (Dąbrowski, Suchodolski, Babski, Kiełczowski, Żółkiewski, etc.), które nosiło wielu rotmistrzów i towarzyszy w armii koronnej tego okresu, gdy „Regestr więźniów" nie zawierał danych umożliwiających identyfikację (imię, urząd, funkcja wojskowa), nie umieszczono komentarza. W zamieszczonych w przypisach objaśnieniach do zawartych w źródle informacji dotyczących jednostek wojskowych wykorzystano rachunki komisji lubelskiej z $1650^{38}$ i ustalenia Jana Wimmera ${ }^{39}$, Marka Rogowicza ${ }^{40}$ i Witolda Biernackiego ${ }^{41}$ dotyczących składu wojsk koronnych biorących udział w bataliach żółtowodzkiej i korsuńskiej.

\section{TEKST ŹRÓDŁOWY}

\section{Regestr więźniów}

Oryginat. Geheimes Staatsarchiv Preussischer Kulturbesitz Berlin-Dahlem, XX Hauptabteilung, Etats Ministerium 111h, nr 152, k. 181-183v. Papier dwustronnie zapisany, pismo czytelne, atrament koloru czarnego. Stan zachowania dobry.

[k. 182 (paginacja oryg. 1)]

Regestr więźniów, ci siedzą

P. Aleksander Andrzejowski ${ }^{42}$

38 „Zapłata wojskom”, k. 5-18. „Likwidacyja wojsk Rzeczypospolitej na komisyjej lubelskiej 1650", Biblioteka Uniwersytetu Wrocławskiego, rkps akc. 1949/440, Polonica, Varia, t. III, k. 431 v-432 [dalej: „Likwidacyja wojsk”].

39 J. Wimmer, Materiały do zagadnienia organizacji i liczebności armii koronnej $w$ latach 1648-1655, „Studia i Materiały do Historii Wojskowości” 1960, t. V, Warszawa, s. 477-509.

${ }^{40}$ M. Rogow i c z, Skład sił polskich nad Żóttymi Wodami i pod Korsuniem w 1648 roku, ,Przegląd Historyczno-Wojskowy" 2015, t. XIV, z. 2, s. 39-62.

41 W. Biernacki, op. cit., s. 86-88, 143-145.

42 Aleksander Andrzejowski, elektor Władysława IV w 1632 r. z województwa lubelskiego, Elektorowie królów Władysława IV, Michała Korybuta, Stanisława Leszczyńskiego i spis stronników Augusta III, opr. J. Dun in - B or k ow s ki, M. D un in - W ą s ow i c z, ,Rocznik Towarzystwa Heraldycznego we Lwowie”, t. I, 1908/1909, s. 1, zapewne tożsamy z wymienionym w „Regestrze kompaniej” „panem 


\section{P. Drzewicki \\ P. Kiełczowski \\ W. Perekopie \\ P. Gromacki ${ }^{43}$ \\ P. Wawrzyn Wychrowski ${ }^{44}$ \\ P. Sam[uel] Czechowski \\ P. Paw[eł] Unisowski ${ }^{45}$ \\ P. Rosowski \\ P. Franc[iszek] Janowski \\ P. Dołgiert ${ }^{46}$}

Jandrzejowskim” spod chorągwi (husarskiej) Jana Kazimierza (,spod chorągwie Króla J.M. teraźniejszego"), zapewne nowo utworzonej w 1649. Poprzednia chorągiew husarska Jana Kazimierza została rozbita pod Korsuniem. Podczas kampanii beresteckiej w 1651 r. Aleksander Jędrzejowski był chorążym w chorągwi dworzańskiej Jana Kazimierza (Regestr dworzan JKM. pocztów pod choragiew benedykowana, turkusowa, adamaszkowa, podwiedzionych $w$ Warszawie, w Lublinie i pod Sokalem - na wyprawe berestecka 1651 r. [w:] Relacje wojenne, s. 341; M. Na gi elsk i, Choragwie dworzańskie Jana Kazimierza podczas dwóch batalii kozackich 1649-1651 [w:] Gospodarka, ludzie władza. Studia historyczne ofiarowane Juliuszowi Łukasiewiczowi w 75 rocznicę urodzin, red. M. Kopczyński, A. Mączak, Warszawa 1998, s. 117, 119, 125).

${ }^{43}$ Prawdopodobnie towarzysz chorągwi husarskiej starosty śniatyńskiego Piotra Potockiego, zniesionej pod Korsuniem. „Likwidacyja wojsk”, k. 431v. W „Regestrze kompaniej” wymieniony jako chorąży w chorągwi husarskiej księcia Karola Koreckiego, wchodzącej w skład armii koronnej od drugiego kwartału 1649 r., do której Gromacki mógł się zaciągnąć po powrocie z niewoli.

${ }^{44}$ Wichrowski? Wichroński?

${ }^{45}$ Uniszewski? Paweł Uniszewski podpisał w 1632 r. elekcję Władysława IV z województwem nowogródzkim, Elektorowie..., s. 242. Uniszewski (bez imienia) został wymieniony w testamencie Jeremiego Wiśniowieckiego z 1651 r. jako towarzysz nadwornej chorągwi husarskiej rotmistrza Jana Grabie Wolskiego. Testament Jeremiego Wiśniowieckiego, wyd. W. To mkie wi c z, „Miesięcznik Heraldyczny" 1930, R. IX, nr 4, s. 75. Rota ta jednak została utworzono dopiero wiosną 1649 z części chorągwi husarskiej stolnika bracławskiego Jana Baranowskiego. „Zapłata wojskom”, k. 38-38v; Płaca pocztom panięcym wr. 1650, wyd. A. S a w czyński, „Przegląd Historyczno-Wojskowy” 1937, t. IX, s. 121), nie mogła więc brać udziału w walkach nad Żółtymi Wodami i pod Korsuniem. Porucznikiem chorągwi Wolskiego w 1651 r. był Czeski, który pod Korsuniem dowodził kwarcianą chorągwią husarską Jeremiego Wiśniowieckiego. Czeski dostał się wówczas do niewoli, którą opuścił przed 22 XI 1648 („Regestr kompaniej”). W skład chorągwi Wolskiego w 1651 r. mogli więc wejść, podobnie jak Czeski, i inni towarzysze z owej chorągwi kwarcianej, w tym Uniszewski. Mógł on zresztą służyć w innej jednostce prywatnej wojewody ruskiego, gdyż takowe walczyły nad Żółtymi Wodami (w kompanii dragonów, zob. W. Maje w ski, Żólte Wody - 1648 r. ..., s. 25; oraz W. B i e r n a c ki, op. cit., s. 87; ostatnio podważył tę tezę M. Rogowic z, op. cit., s. 47-48)) i pod Korsuniem (pułk pod komendą strażnika koronnego Aleksandra Zamojskiego, List Jakuba Betchackiego, 90; Relacyja jednego niedobitka muszkietera spod regimentu pana Henryka Denoffa obersztera o pogromie panów hetmanów pod Korsuniem. Relacje wojenne... (dalej: Relacyja muszkietera) s. 116; M. Rogowicz, op. cit., s. 53; W. Biernacki, op. cit., s. 142). Zapewne inny Uniszewski był porucznikiem nowej, utworzonej w 1649 r. (poprzednia została rozbita pod Korsuniem) chorągwi husarskiej Jerzego Lubomirskiego, która brała udział w obronie Zbaraża, „Likwidacyja wojsk”, k. 432v.

${ }^{46}$ Dowgird?, Dougiert?, Dangiert? Prawdopodobnie Dangiert, porucznik rozbitej pod Kosuniem chorągwi husarskiej kasztelana czernihowskiego i starosty winnickiego Jana Odrzywolskiego. „Likwidacyja wojsk”, k. 431v. Znany jest z tego okresu również Aleksander Dougiert, porucznik chorągwi husarskiej ks. Koreckiego w latach 1649-1650, uczestnik obrony Zbaraża w lipcu i sierpniu 1649. AGAD, 


\author{
W. Karosowie ${ }^{47}$ \\ P. Lippski spod chorągwi Króla J.M.48 \\ P. Dombrowski ${ }^{49}$ \\ P. Klembowski chorąży \\ P. Pruskowski \\ Pułkownicy w Bayze Saray ${ }^{50}$ \\ P. Górski ${ }^{51}$ \\ P. Korsuński ${ }^{52}$
}

ASW dz. 86, nr 38, k. 13; „Likwidacyja wojsk”, k. 432; Pamiętniki..., t. II, s. 61; W. Kochow sk i, Historia panowania Jana Kazimierza, wyd. E. Ra czyń s k i, Poznań 1859, t. I, s. 49.

${ }^{47}$ Karasu (Karasubazar, obecnie Biełogorsk) miasto na południu Krymu, pomiędzy Akmesdżid (Symferopol) a Kaffą.

${ }^{48}$ W bitwie pod Korsuniem brały udział chorągwie husarskie króla Władysława IV (,zmarłego”) i królewicza Jana Kazimierza („teraźniejszego” w momencie redagowania „Regestru więźniów”).

${ }^{49}$ Dąbrowskiego w grupie jeńców w Jassach wymienia „Regestr niewolników”.

${ }^{50}$ Bachczysaraj.

${ }^{51}$ Być może był to Wojciech Gurski (Górski), setnik pułku kaniowskiego Kozaków regestrowych, uczestnik obrony Zbaraża, nobilitowany na sejmie 1650 r., któremu komisja lubelska w marcu $1650 \mathrm{r}$. przyznała traktament i żołd za sześć lat służby (od 1 XII 1643 do 28 II 1650). „Instrukcja [...] posłom wojskowym”, s. 44; „Suppliki od Kozaków zaporowskich w poselskiej izbie I.M. Panom posłom podane”. APG 300, 29/133, k. 321-321v; „Zapłata wojskom”, k. 15v; Volumina legum, t. IV, Petersburg 1860, s. 155; W.A. Serc zy k, Na płonacej Ukrainie. Dzieje Kozaczyzny 1648-1651, Warszawa 1998, s. 321; S. Ochmann-Staniszewska, Z. Staniszewski, Sejm Rzeczypospolitej za panowania Jana Kazimierza Wazy. Prawo - doktryna - praktyka, t. I, Wrocław 2000, s. 67; Ł. Częścik, op. cit., s. 95 (podaje nazwisko Porski). Wydaje się, że mimo zbieżności imienia i nazwiska nie należy go utożsamiać z wymienionym poniżej pułkownikiem korsuńskim. Zapis nie dotyczy zapewne również przebywającego w tym samym czasie w niewoli tatarskiej Jana Gurskiego (Zapłata wojskom, k. 7), towarzysza rozbitej pod Korsuniem chorągwi husarskiej starosty sądeckiego Konstantego Lubomirskiego, nagłówek ,pułkownicy” rozróżnia wymienionych pod nim od innych jeńców jako starszyznę Kozaków regestrowych.

${ }^{52}$ Wojciech Górski (Gurski), pułkownik korsuńskiego pułku Kozaków regestrowych, rotmistrz chorągwi kozackiej i dragońskiej, brał udział w kampanii żółtowodzkiej w tzw. grupie wodnej (Diariusz z pierwszego okresu buntu Bohdana Chmielnickiego spisany przez towarzysza spod choragwi kozackiej wziętego do niewoli pod Kniażymi Bajrakami. Relacje wojenne..., s. 96, 100; Kopia listu pana (Krzysztofa) Koryckiego pułkownika książęcia jmci pana wojewody sandomirskiego (Dominika Zastawskiego-Ostrogskiego) z 12 maja 1648 r. przed ostatecznym pogromieniem wojska u Żóltych Wód. Документы..., s. 28-29 (dalej: Kopia listu Koryckiego)). Według relacji Koryckiego Górski wraz z dwoma innymi pułkownikami Kozaków regestrowych: czehryńskim Stanisławem Krzeczowskim i czerkaskim Stanisławem Wadowskim oraz starszyzną grupy wodnej zostali zamordowani po wzięciu do niewoli. Por. Relacje wojenne..., s. 114; A.S. Radziwiłł, Pamiętnik o dziejach w Polsce, t. III, 1647-1656, wyd. A. Przyboś, R. Że lew ski, Warszawa 1980, s. 75). W. Biernack i (op. cit., s. 111) stwierdza, że pułkownicy ocaleli, ale nie powołuje się przy tym na żadne źródło. Tymczasem w kronice Hadży Mehmeda Senai (Historia chana Islama Gereja III, wyd. Z. Abrahamowicz, Warszawa 1971, s. 51) czytamy: „Oto osiemdziesięciu giaurów polskich pełniących władzę i dowództwo nad trzema tysiącami pięciuset Kozaków dnieprzańskich, którzy przedtem przybyli czajkami na rzekę Dniepr, oddali na pastwę miecza, głównych zaś i najważniejszych z nich - trzech znakomitych giaurów zwanych «pułkownikami» w kajdany". Pobyt pułkownika korsuńskiego Górskiego (błędnie z imieniem Paweł) w niewoli w Bachczysaraju (,u chana siedzi”) potwierdza „Regestr niewolników”. Por. M. Nagi elski, Sytuacja jeńców..., s. 576. 


\author{
P. Brzuchański białocerkiewski ${ }^{53}$ \\ P. Wowiłowic kaniowski ${ }^{54}$ \\ W. Merkiucie siedzą \\ P. Kunarski \\ P. Chrząstowski ${ }^{55}$ \\ P. Kusnowski \\ Blisko tejże wsi \\ P. Domaniowski porucznik \\ P. Zaniewski ${ }^{56}$ \\ P. Żołkiewski ${ }^{57}$
}

${ }^{53}$ Aleksander Brzuchański, pułkownik białocerkiewskiego pułku Kozaków regestrowych, rotmistrz chorągwi kozackiej i dragońskiej, uczestniczył w kampanii żółtowodzkiej w tzw. grupie lądowej. Wysłany 14 IV 1648 wraz ze Stefanem Czarnieckim i Gabrielem Woyniłłowiczem do obozu tatarskiego jako poseł (zakładnik?) został zatrzymany w niewoli przez Tuhaj beja. Diariusz z pierwszego okresu buntu..., s. 96, 104; Raport pachołka ..., s. 114; Kopia listu Koryckiego..., s. 29; W. B i e r n a c k i, op. cit., s. 115-117; A. Kersten, Stefan Czarniecki 1599-1665, Warszawa 1963, s. 129, 132-133; W.A. S erczyk, op. cit., s. 71; T. Krząstek, W. Majewski, M. Nagielski, I.S. Storożenko, op. cit., s. 31, 73, 89, 93, 95. Anonimowa relacja z Czerkas z 20 V 1648 błędnie informuje, że Brzuchański wchodził w skład grupy wodnej i został zamordowany przez Kozaków. Джерела..., t. I, s. 21. Nie wiadomo, kiedy opuścił niewolę, według listu nieznanego autora do kanclerza w. kor. Jerzego Ossolińskiego z Mikuliniec z 22 XI 1649 znajdował się w grupie jeńców wracających z Krymu przez Mołdawię, którzy na żądanie Kozaków zostali zawróceni i zatrzymani w niewoli, APG 300, 29/133, k. 306. Podczas kampanii beresteckiej w 1651 r. Brzuchański dowodził chorągwią kozacką, Relacje wojenne..., s. 350.

${ }^{54}$ Gabriel Woyniłłowicz (zm. 1664?), pułkownik kaniowskiego pułku Kozaków regestrowych od 1 III 1648, rotmistrz chorągwi kozackiej i dragońskiej, brał udział w kampanii żółtowodzkiej w tzw. grupie lądowej. Wysłany 14 IV 1648 wraz ze Stefanem Czarnieckim i Aleksandrem Brzuchańskim do obozu tatarskiego jako poseł (zakładnik?), został zatrzymany w niewoli przez Tuhaj beja. Diariusz z pierwszego okresu buntu..., s. 96, 103 (tu mylnie wymieniony w składzie grupy wodnej); Raport pachołka spod choragwi Stanisława Mariusza Jaskólskiego o bitwie u Żóltych Wód. Relacje wojenne, s. 112 [jako Wonmełowicz]; Kopia listu Koryckiego, s. 29; W. B iern ack ki, op. cit., s. 115-117, 200; A. Kersten, Stefan Czarniecki..., s. 129, 132-133; W.A. Serczyk, op. cit., s. 71; T. Krząstek, W. Majew ski, M. Nag ielsk i, I.S. St orożenk o, op. cit., s. 31, 73, 89, 93, 95. W 1651 r. w służbie Jeremiego Wiśniowieckiego, porucznik chorągwi husarskiej stolnika bracławskiego Jana Baranowskiego (1651), rotmistrz chorągwi kozackiej (1651-1653), porucznik chorągwi kozackiej hetmana polnego, od 1654 r. wielkiego koronnego Stanisława „Rewery” Potockiego (1653-1655), porucznik chorągwi kozackiej króla Jana Kazimierza (1656-1663), starosta lityński (już w 1660), zginął (lub zmarł w wyniku odniesionych ran) prawdopodobnie w 1664 podczas kampanii zadnieprzańskiej przeciw Moskwie. S. A u gusiew ic z, Gabriel Woynitlowicz, oficer jazdy koronnej z pot. XVII w. Zarys Biografii, „Studia z Dziejów Wojskowości” 2012, t. I, s. 101-127.

55 Zapewne Hieronim Chrząstowski, rotmistrz chorągwi kozackiej rozbitej pod Korsuniem (Diariusz z pierwszego okresu buntu..., s. 103) mylnie wymienia ją w składzie grupy wodnej podczas wyprawy żółtowodzkiej. Zob. A. Kersten, Stefan Czarniecki..., s. 129; M. Rog ow ic z, op. cit., s. 41, 43, 56). Hieronim Chrząstowski był rotmistrzem chorągwi kozackiej już w 1637 r., brał udział w walkach z Kozakami w latach 1637-1638. Korespondencja Stanistawa Koniecpolskiego, hetmana wielkiego koronnego, opr. A. B ie drzy ck a, Kraków 2005, s. 448-449, 454, 487,491, 493, 500-505; M. G a w ę da, Powstanie kozackie 1637, Zabrze 2007, s. 176, 199; A. B or ow iak, Powstanie kozackie 1638, Zabrze 2010, s. 57, 62-63, 72-73, 79, 100, 104, 112, 117, 128, 166-167.

56 „Regestr niewolników” wymienia Jędrzeja Zaniowskiego.

${ }^{57}$ Według informacji rotmistrza Aleksandra Żółkiewskiego (h. Bończa, z ziemi chełmskiej) pod Korsuniem zginął jeden z jego bratanków, Łukasz, a drugi, nieznany z imienia, dostał się do niewoli; 


\author{
Pod Białogrodem \\ P. Kalinowski porucznik ${ }^{58}$ \\ P. Gronecki \\ P. Barycko \\ W Jasiech, którzy są \\ P. Gniewosz ${ }^{59}$ \\ [k. 182v (paginacja oryg. 1v)] \\ P. Borzewicki ${ }^{60}$ \\ P. Brzeziński ${ }^{61}$ \\ P. Chomentowski ${ }^{62}$ \\ P. Ziemiecki ${ }^{63}$ \\ P. Druszkiewicz ${ }^{64}$
}

A. Żółkiewski do J. Ossolińskiego, Dubno 8 VI 1648. APG 300, 29/129, k. 121; APG 300, R, Ee 32, s. 248; Michałowski, s. 35; Szajnocha, s. 341; M. Wagner, Słownik biograficzny oficerów polskich drugiej połowy XVII wieku, t. I, Oświęcim 2013, s. 320-322; K. Niesieck ki, Herbarz polski, wyd. J.P. B obrowicz, t. X, Lipsk 1845 (dalej: Ni e si e ck i), s. 183-188.

${ }^{58}$ Jan Kalinowski, miecznik bracławski od 1631, porucznik chorągwi husarskiej wojewody czernihowskiego i hetmana poln e go koronnego Marcina Kalinowskiego zniesionej pod Korsuniem, nowo utworzonej w 1649, wykupiony z niewoli przed 3 VII 1649. „Regestr kompaniej”; „Likwidacyja wojsk”, k. 431v; AGAD, ASW dz. 86, nr 38, k. 7; AGAD, ASW dz. 86, nr 40, k. 8v; Metryka Ruska (Wotyńska). Regesty dokumentów z kancelarii koronnej dla ziem ukraińskich (województw wolyńskiego, bractawskiego, kijowskiego i czernihowskiego) 1569-1673, Kijów 2002, s. 643; Джерела..., t. I, s. 275; Ojczyste spominki..., t. II, s. 55.

${ }^{59}$ Stanisław Gniewosz, siostrzeniec kanclerza w. kor. Jerzego Ossolińskiego, towarzysz chorągwi husarskiej króla Władysława IV, do niewoli wzięty pod Korsuniem, wykupiony w Jassach przez Michała Milicza przed 3 VII 1649. J. Ossoliński do A.H. Sieniawskiego, Warszawa 19 VI 1648. Szajnocha, s. 347-348; „Regestr niewolników”; „Regestr kompaniej”; S.Z. Dru szki ew icz, op. cit., s. 89; Джерела..., t. I, s. 275; Ojczyste spominki..., t. II, s. 55.

${ }^{60}$ Borzewicki (Borżowicki?) został wykupiony w Jassach przez Michała Milicza przed 3 VII 1649, S.Z. Dru szki e w icz, op. cit., s. 89; Джерела..., t. I, s. 275; Ojczyste spominki..., t. II, s. 55. „Likwidacyja wojsk" (k. 432) wymienia Borżewickiego jako porucznika nowo utworzonej w 1649 r. chorągwi husarskiej Konstantego Lubomirskiego, która brała udział w obronie Zbaraża.

${ }^{61}$ Jeńca Brzezińskiego wymieniał w relacji z Konstantynopola z 30 stycznia 1649 r. Wojciech Bieczyński: „krewny nieboszczyka księdza Trzebińskiego [biskupa przemyskiego i podkanclerzego koronnego Aleksandra Trzebińskiego w 1. 1643-1644?]. [...] Tenże szacował się na pięćset talarów". Michałowski, s. 362. Być może tegoż Brzezińskiego wykupił z niewoli Milicz. S.Z. Druszkiewicz, op. cit., s. 89.

${ }^{62}$ Stefan Chomentowski (Chomętowski) (zm. 1651), podczaszy bełski (w 1. 1643-1648), sędzia wojskowy (1638), rotmistrz chorągwi kozackiej, wśród jeńców spod Korsunia wymieniony w relacji Pawła Kochana z Baru z 5 VI 1648, Документы ..., s. 38. Pamiętniki..., t. I, s. 287; Relacje wojenne..., s. 123; S zaj no ch a, s. 75; Korespondencja Stanistawa Koniecpolskiego..., s. 437; M. Wa g ne r, Stownik biograficzny oficerów polskich drugiej połowy XVII wieku, t. II, Oświęcim 2014, s. 52-53.

${ }^{63}$ Towarzysz chorągwi husarskiej Jerzego Bałabana, zniesionej pod Korsuniem, niewolę opuścił przed listopadem 1649. Zob. „Regestr kompaniej”.

${ }^{64}$ Stanisław Zygmunt Druszkiewicz (1621-1690), wojski halicki (1656), podstoli parnawski (1660), kasztelan lubaczowski, chełmski (1685), rotmistrz i pułkownik jazy koronnej. Jako towarzysz chorągwi kozackiej Jacka Szemberka brał udział w walkach nad Żółtymi Wodami, gdzie został wzięty do niewoli. Początkowo przebywał na Krymie, potem w Kaffie. Wykupiony przez Milicza zapewne przed 3 VII 1649. Po raz drugi dostał się do niewoli tatarskiej pod Batohem w 1652 r. „Regestr 


\author{
P. Kaski ${ }^{65}$ \\ P. Obułtowski \\ P. Dombrowski \\ Ci pomarli w więzieniu \\ P. Niebowarski \\ P. Borkiewic \\ P. Anchigier ${ }^{66}$ \\ P. Czetner \\ P. Iżycki \\ P. Wałdoski \\ P. Jakubowski \\ P. Żółkiewski młody \\ P. Bobowskich dwóch \\ P. Stefan Komorowski ${ }^{67}$
}

niewolników", S.Z. Drus zki ew i c z, op. cit., s. 9-10, 87-89; K. P iw ar ski, Druszkiewicz Stanisław Zygmunt (1621-1690). PSB, t. V, s. 400.

65 Jan Kaski (zm. 1665), sędzia wojskowy, cześnik kamieniecki (1655-1665), rotmistrz piechoty polskiej (1654-1662). Do niewoli dostał się pod Korsuniem, gdzie walczył jako towarzysz chorągwi husarskiej Jana Kazimierza. Uwolniony przed 3 VII 1649, jesienią tegoż roku znalazł się w obozie wojskowym pod Lwowem. Był jednym z inicjatorów związku wojskowego w styczniu 1650 i dyrektorem koła rycerskiego w marcu 1650. W latach 1650-1651 towarzysz chorągwi husarskiej hetmana w. kor. Mikołaja Potockiego. AGAD, ASW dz. 86, nr 38, k. 3v; AGAD, ASW dz. 86, nr 40, k. 3; Джерела..., t. I, s. 275; Ojczyste spominki..., t. II, s. 55; Urzędnicy podolscy XIV-XVIII w., opr. E. J a n a s, W. Kła c zew ski, J. Kurtyk a, A. S o ch a cka, Kórnik 1998, s. 59, 209; E. Ja n a s, op. cit., s. 19-20; M. Wa gner, Stownik biograficzny..., t. I, s. 142.

66 Achinger?

${ }^{67}$ W źródłach z poł. XVII w. znajdujemy kilku Stefanów, członków różnych rodzin żyjących na Litwie i w Koronie. Wymieniany w większości relacji tylko z nazwiska, wzięty do niewoli pod Korsuniem Komorowski to Piotr h. Ciołek, podstoli podolski (od 1644), rotmistrz chorągwi kozackiej (już w 1637) i uczestnik walk z Kozakami w latach 1637-1638, komisarz Kozaków rejestrowych od 1638, rotmistrz chorągwi kozackiej (A. Przyboś, Komorowski Piotr h. Ciołek (zm. ok. 1654), PSB, t. XIII, s. 430431; M. Wagner, Stownik biograficzny..., t. I, s. 150-151). Bratem Piotra był Stefan (A. B on i e k i, Herbarz polski, t. X, Warszawa 1907 (dalej: Boniecki), s. 382; S. Uru ski, Rodzina. Herbarz szlachty polskiej, t. VII, Warszawa 1910 (dalej: Uruski), s. 136, nie można wykluczyć, że to właśnie on został wymieniony w rejestrze. Wydaje się, że zapis nie dotyczy chyba najbardziej znanego, rotmistrza chorągwi kozackiej w latach 1649-1650, Stefana Komorowskiego h. Korczak, syna podczaszego bełskiego i podstarościego krakowskiego Jana. Tenże nie uczestniczył w walkach nad Żółtymi Wodami i pod Korsuniem, 15 VI 1648 sejmik halicki powierzył mu stanowisko rotmistrza kozackiej chorągwi powiatowej, która w październiku tegoż roku znajdowała się w Zamościu i przeszła na utrzymanie skarbu państwa (tzw. zaciąg zamojski). Zapewne to on podpisał elekcję króla Michała Korybuta w czerwcu 1669. „Zapłata Wojskom”, k. 30; „Likwidacyja wojsk”, k. 432v; Uchwała sejmiku bełskiego, 15 VI 1648. Жерела до істориї Украӥни Руси, t. IV, Материяли до істориї Галичини, зіб. С. Томашів сь и й, t. I, Львїв 1898, s. 3, 8; D. Ku u is z, Wojska powiatowe samorządów Małopolski i Rusi czerwonej w latach 1572-1717, Lublin 2008, s. 259, 395; Elektorowie..., s. 96; Nies i e cki, t. V, s. 173; Uru ski, t. VII, s. 144. Można w tym przypadku wykluczyć również Stefana Komorowskiego h. Habdank z województwa brzesko-kujawskiego, odnotowanego w 1651 r. B oni ecki, t. X, s. 391. Może był to Stefan Komorowski z woj. czernihowskiego, wymieniony w 1636 r. Z dziejów Ukrainy. Księga pamiątkowa ku czci Włodzimierza Antonowicza, Paulina Święcickiego i Tadeusza Rylskiego, red. W. Li pińs ki, Kijów 1912, s. 212. 


\section{P. Janusz Dombski ${ }^{68}$ \\ P. Dubraski \\ P. Branicki \\ P. Skinder \\ P. Małowski ${ }^{69}$ \\ P. Piotrowski \\ P. Stamirowski \\ P. Wasiuczinski \\ Tych za morze poprzedano \\ P. Kowalowski ${ }^{70}$ pułk kaniowski \\ P. Swisczewski z Czerkas \\ P. Czerkies \\ P. Strasz ${ }^{71}$ \\ P. Sulinia ${ }^{72}$ pułkownikowi kaniowskiemu [służył] \\ P. Graszewski towarzysz pana starosty sądeckiego ${ }^{73}$}

[k. 183, oryg. pag. 2]

P. Winnicki towarzysz pana kamienieckiego ${ }^{74}$

P. Dunin [towarzysz] J.M.P. Sieniawskie[go] ${ }^{75}$

${ }^{68}$ Znani są Dąbscy (Dombscy) Marek, Remigian i Jarosz, towarzysz chorągwi husarskiej Konstantego Lubomirskiego, którzy do niewoli tatarskiej dostali się nad Żółtymi Wodami lub pod Korsuniem. Ostatni z nich został uwolniony najpóźniej jesienią 1649 r. „Regestr kompaniej”, „Zapłata wojskom”, k. 7; Niesiecki, t. III, s. 294.

${ }^{69} \mathrm{~W}$ „Regestrze niewolników”: „Jan Małoski, w Kaci u popa Efendego pod Karaszewem z strażnikiem".

${ }^{70}$ Wymieniony także w „Regestrze niewolników”. Być może był to Jan Kowalowski, Kozak któregoś z pułków regestrowych, który po unii hadziackiej otrzymał na sejmie w maju 1659 dobra Skwirę i Romanówkę położone w woj. kijowskim. W. Lipińs ki, Dwie chwile z dziejów porewolucyjnej Ukrainy [w:] Z dziejów Ukrainy..., s. 609.

${ }^{71}$ W „Regestrze niewolników”: Jan Strasz.

72 Sulima. Po unii hadziackiej, na sejmie w maju 1659, w grupie Kozaków którzy otrzymali nadania ziemskie w woj. kijowskim znalazło się trzech braci Sulimów: Stefan (starszy), Stefan (młodszy) i Teodor. Źródła potwierdzają pobyt w niewoli Teodora, Руська (Волинська) метрика. Книга за 1652-1673 pp., уклад. П. Кулаковський, Острог-Варшава-Москва 1999, s. 119-123; 161-162, 164-165; Metryka Ruska ..., s. 768-769; W. Li pińs k i, op. cit., s. 608-609.

${ }^{73}$ Chorągwi husarskiej Konstantego Lubomirskiego, rozbitej pod Korsuniem.

${ }^{74}$ Pod Korsuniem walczyły dwie chorągwie, kozacka (pod porucznikiem Mikołayem) i wołoska, Piotra Potockiego, starosty kamienieckiego, syna hetmana w. kor. Mikołaja Potockiego. M. Nagielski, Potocki Piotr h. Pilawa (zm. 1657), PSB, t. XXVIII, s. 121-124. M. Rogowi cz (op. cit., s. 56) przypisuje mu rotmistrzostwo biorącej również udział w tej bitwie chorągwi husarskiej, mylnie utożsamiając go z jej rotmistrzem, starostą śniatyńskim Piotrem Potockim, synem woj. bracławskiego Stefana. M. N a g i ls ki, Potocki Piotr h. Pilawa (zm. 1648); PSB, t. XXVIII, s. 119-121.

${ }^{75}$ Chorągiew husarska starosty lwowskiego, pisarza pol. kor. Adama Hieronima Sieniawskiego, została rozbita pod Korsuniem. Sam Sieniawski dostał się do niewoli, ale, co poświadczają liczne relacje z tego okresu, został uwolniony przez Tuhaj beja za poręczeniem Mikołaja Potockiego i zobowiązaniem do okupu 20 tys. zł, 30 koni i zwolnienia znajdujących się u niego jeńców tatarskich. Z obietnicy nie wywiązał się, co utrudniało potem negocjacje z Tatarami, m.in. dotyczące wykupienia z niewoli hetmanów, a potem stało się przyczyną procesów spadkobierców hetmana z wdową po Sieniawskim. 
Co w Krymie siedzą towarzystwo

J.M.P. Bieganowski oboźny ${ }^{76}$

P. Komorowski Stefan i syn jego co służył J.M.P. Chomentowski[emu] $]^{77}$

P. Hieronim Babski

P. Andrzej Drapkowski ${ }^{78}$

P. Bałabanow ${ }^{79}$

P. Minocki porucznik

P. Plika

P. Konstanty Browicki ${ }^{80}$

P. Chowinski

P. Stefan Młodzianowski

Brał udział w bitwie pod Piławcami 23 IX 1648 i obronie Zbaraża (lipiec-sierpień 1649). Na sejmie 1649/1650 wyznaczony do komisji wojskowej, zmarł 25/26 I 1650, wkrótce po opuszczeniu Warszawy. APG 300, 29/129, k. 121; APG, 300, R, Ee 32, s. 244, 248-250, 259, 278; Szajnocha, s. 340, 342, $347-$ 348; Pamiętniki..., t. I, s. 287; Hadży Mehmed Senai, op. cit., s. 107; Джерела..., t. I, s. 32, 35, 51, 53-54; Документыл..., s. 37, 41-42, 76; Michałowski, s. 34-35, 39, 52; Жерела до істориї України Руси..., s. 41, 104; M. Na gi i lsk i, Sytuacja jeńców..., s. 566-567; M. Na gi el sk ki, Z dziejów jasyru..., s. 55; idem, Sieniawski Adam Hieronim z Granowa (1623/24-1650). PSB, t. XXXVII, s. 102-105; W. Bi ernacki, op. cit., s. 180; A. Kersten, Stefan Czarniecki..., s. 134.

${ }^{76}$ Mikołaj Bieganowski (1601-1674), oboźny wojskowy 1635-1648, 1650-1652, brał udział w bitwie pod Kumejkami w 1637 r., podstoli lwowski (1643-1644), chorąży lwowski (1644-1658), kasztelan podlaski (1658-1660), kasztelan kamieniecki (1660-1674), dyplomata (posel do Turcji w latach 1634, 1643, 1654), rotmistrz jazdy i dragonii. Do niewoli dostał się pod Korsuniem, według relacji Pawła Kohana z 5 VI 1648: „P. Bieganowski jest u sołtanika, tego wysoce sobie szacują i mają go w dobrym sekwestrze", Документы ..., s. 38, 108; APG 300, 29/129, k. 107v; APG, 300, R, Ee 32, s. 244; Джерела..., t. I, s. 35, 43; Szajnocha, s. 342; Pamiętniki..., t. I, s. 87; W. B i er n a ck i, op. cit., s. 180; A. Kersten, Stefan Czarniecki..., s. 134; M. Wa gn er, Stownik biograficzny..., t. I, s. 23-25; E. Lat a c z, Bieganowski Mikołaj h. Grzymała (1601-1674), PSB, t. II, s. 26-27.

${ }^{77}$ W chorągwi kozackiej Stefana Chomentowskiego, rozbitej pod Korsuniem.

${ }_{78}$ Porucznik chorągwi husarskiej Jerzego Bałabana, rozbitej pod Korsuniem. „Likwidacyja wojsk”, k. 431v; M. Rogowicz, op. cit., s. 56. Być może to jego wymienia „Regestr niewolników”: „p. Drackowski, siedzi u Manet Gadży, co do Bożego grobu chodzi, w Bachczysaraju na Hulajczyku podle bramy".

79 Jerzy Bałaban, syn pułkownika Aleksandra Bałabana, starosta trembowelski (1633), rotmistrz chorągwi husarskiej już w 1637 r., uczestnik kampanii smoleńskiej 1633-1635 i walk z Kozakami w latach 1637-1638. Dostał się do niewoli tatarskiej pod Korsuniem, uwolniony dopiero we wrześniu $1650 \mathrm{r}$. Wykupienia Bałabana z niewoli mieli się domagać na sejmach 1649/1650 i w grudniu 1650 wojsko koronne oraz posłowie haliccy i ruscy. APG, 300, 29/129, k. 121; APG300, 53/101, s. 38; APG 300, R, Ee 32, s. 248, 259, 454-455; Relacyja muszkietera ..., s. 120, 122; Pamiętniki..., t. I, s. 287; Michałowski, s. 34-35, 39; Szajnocha, s. 340; Джерела..., t. I, s. 88; Джерела..., t. II, s. 25; Жерела до істориї України Руси, t. XII, Матеріяли до історії української Козаччини, t. V, Акти до Хмелниччинии (1648-1657), вид. М. Ко рду ба, Львов 1911, s. 136, 145; Документын..., s. 353; Akta grodzkie i ziemskie z Archiwum Ziemskiego we Lwowie, t. XXIV, Lauda sejmikowe halickie 1575-1695, wyd. A. Prohaska, Lwów 1931, s. 82 (dalej: AGZ, t. XXIV); Akta grodzkie i ziemskie z czasów Rzeczypospolitej Polskiej z archiwum tak zwanego bernardyńskiego we Lwowie, t. XXI, Lauda sejmikowe, t. II, Lauda wiszeńskie 1648-1673, wyd. A. Proh a s ka, Lwów 1911, s. 75 (dalej: AGZ, t. XXI); M. Nag i el sk i, Z dziejów jasyru..., s. 63; A. Kerst en, Stefan Czarniecki..., s. 134; E. Lat a c z, Bałaban Jerzy h. Korczak. PSB, t. I, s. 250-251.

${ }^{80}$ Bronicki? Konstanty Bronicki był poborcą skarbowym woj. wołyńskiego w 1659 r., Metryka Ruska ..., s. 869. 
P. Niemoiowski chorąży pana Kowal[skiego $]^{81}$
P. Glinka synowiec pana halickiego ${ }^{82}$
P. Koterski towarzysz pana Zaćwilichowskie[go] $]^{83}$
P. Luscatinski ${ }^{84}$
P. Proczkowski rotmistrz księcia Wiśniow $\left[\right.$ ieckiego] ${ }^{85}$
P. Satinowski towarzysz pana Gdeszyński[ego ${ }^{86}$
Którzy w Kozłowie $^{87}$ siedzą
P. Stanisław Ślazowski u Hakebeia Murzy
P. Kuropatwa towarzysz Pana starosty kamienieckiego
P. Kurowski u Suinagi Turczyna tal. 500
P. Wojciech Troianski ${ }^{88}$ sługa księcia Wiśniowiec[kiego]

${ }^{81}$ Stefan Kowalski, rotmistrz chorągwi kozackiej już w 1646 r. (Korespondencja Stanisława Koniecpolskiego, s. 688), wśród jeńców spod Korsunia wymienia go Paweł Kochan. Документы ..., s. 38; Pamiętniki..., t. I, s. 287; Джерела..., t. I, s. 88; Relacje wojenne..., s. 123.

${ }^{82}$ Być może był to bratanek Jana Glinki h. Trzaska, łowczego halickiego w latach 1627-1648, Urzędnicy województwa ruskiego XIV-XVIII wieku (Ziemie halicka, lwowska, przemyska, sanocka), opr. K. Przy boś, Wrocław 1987, s. 47; Uruski, t. IV, s. 176; Ni esiecki, t. IV, s. 145; B on iecki, t. VI, s. 74.

${ }^{83}$ Chorągiew kozacka wojskiego winnickiego Mikołaja Zaćwilichowskiego brała udział w kampanii żółtowodzkiej w grupie lądowej. Raport pachołka..., s. 112; Kopia listu Koryckiego..., s. 29; List Jakuba Betchackiego..., s. 91. Sam Zaćwilichowski, rotmistrz już ok. 1625 r., komisarz wojsk zaporoskich po Piotrze Komorowskim już w 1644 r., uczestnik bitwy pod Ochmatowem w tymże roku, nie uczestniczył w wyprawie i nie trafił do niewoli. W 1649 r. bronił Zbaraża, gdzie został ranny w rękę, w lipcu posłował do Chmielnickiego. W 1651 r. brał udział w kampanii beresteckiej i białocerkiewskiej. „Instrukcja [...] posłom wojskowym w kole generalnym pod Lwowem na sejm walny warszawski, die 22 Novembris 1649”, s. 42-43; Relacje wojenne..., s. 107, 139, 177, 278, 303-304, 310; W. Maj ew s ki, Żólte Wody - 1648 r..., s. 32.

${ }^{84}$ Lisiczyński?

${ }^{85}$ Zapewne Jeremiego Wiśniowieckiego, którego jednostki nadworne brały udział w walkach nad Żóltymi Wodami i pod Korsuniem. Wśród nich oraz pozostałych, także w późniejszych latach nie znajdujemy rotmistrza o takim nazwisku. Laudum sejmiku halickiego z 15 III 1649 wymienia ,p. Rzeczkowskiego młodego, który na Żółtych Wodach w nieprzyjacielskie dostawszy się ręce, teraz powrócił”. AGZ, t. XXIV, s. 76. Być może był to Jerzy Rzeczkowski h. Boża Wola, który już w latach trzydziestych służył u Wiśniowieckiego i brał udział w walkach z Kozakami. W 1649 r. dowodził chorągwią piechoty zaciągu polskiego, biorącej udział w obronie Zbaraża, w 1651 został porucznikiem chorągwi kozackiej. „Zapłata wojskom”, k. 37v; AGAD, ASW dz. 86, nr 40, k. 77v; Płaca pocztom panięcym..., s. 122; M. Wa gne r, Stownik biograficzny..., t. I, s. 243.

${ }^{86}$ Marek Gdeszyński (zm. 1649), jako rotmistrz brał udział w walkach z Kozakami w 1638 r. Jego chorągiew kozacka została rozbita pod Korsuniem, sam Gdeszyński, ranny w nogę, dostał się do niewoli, z której wkrótce zbiegł. Ranny pod Zborowem 15 VIII 1649, zmarł kilka tygodni później. APG, 300, 29/129, k. 121; APG 300, R, Ee 32, s. 248; Relacyja muszkietera..., s. 115, 117; Документьл..., s. 38; Michałow ski, s. 35; Szajnocha, s. 340; Pamiętniki..., t. I, s. 287; Relacje wojenne..., s. 185, 190-191, 210; Z. La s o c ki, Gdeszyński Marek (zm. 1649). PSB, t. VII, Kraków 1948-1958, s. 361.

87 Kozłów, tatarski Gözlew (Gözlewe, po 1783 Eupatoria), miasto portowe na zachodnim wybrzeżu Krymu nad zatoką Kalamita.

${ }^{88}$ Prawdopodobnie błędnie zapisane osobno nazwiska: Kurowski i Wojeciech Trojański odnoszą się do tej samej osoby: Wojciecha Trajana Kurowskiego, którego znajdujemy w „Regestrze niewolników”. 
P. Kanski ${ }^{89}$ wojewody podolskiego tal. 430

P. Stanisław Rzewski ${ }^{90}$ u Suim Beja tal. 190

Pan Zygmunt Gury u pana Wolinski[ego] ${ }^{91}$ służył tal. 150

P. Schlichtting ${ }^{92}$ u księcia Wiśniow[ieckiego] służył

P. Czerkies panu Jaskólsk[iemu ${ }^{93}$ służył

P. Sulima z pułku kaniowskiego

P. Przedzinski

[s. $183 \mathrm{v}$ oryginalna $2 \mathrm{v}$ ]

P. Ankiewicz ${ }^{94}$

P. Suchodolski

P. Zabokrzycki

P. Tirleski ${ }^{95}$ siedzi dwie mile od Karasowa u Tatarzyna Atalika tal. 600

P. Gosierowski ${ }^{96}$ tal. 500

P. Stefan Trzeciecki

P. Zygmunt Oraczowski ${ }^{97}$ tal. 400

P. Jan Złoczewski tal. 500

P. Dan[iel] Babski tal. 250

${ }^{89}$ Kański, zapewne tożsamy z Janem Kańskim („Regestr niewolników”), towarzysz chorągwi wojewody podolskiego Stanisława Potockiego rozbitej pod Korsuniem (,Regestr kompaniej”), prawdopodobnie wykupiony z niewoli przez Milicza. S.Z. Dru s zk i ew i c z, op. cit., s. 89.

${ }^{90}$ Można wykluczyć, że był on tożsamy z ówczesnym podstolim bracławskim Stanisławem Rzewuskim, gdyż ten uczestniczył w listopadzie 1648 r. w elekcji Jana Kazimierza. M. N a g i els k i, Rzewuski Stanistaw h. Krzywda (zm. 1668), PSB, t. XXXIV, s. 151-152.

${ }^{91}$ Chorągiew kozacka Stefana Franciszka Wolińskiego pod porucznikiem Gidzińskim została rozbita pod Korsuniem. Brak informacji, aby Woliński również dostał się do niewoli. M. Wag n er, Stownik biograficzny..., t. I, s. 295.

92 Szlichtyng był towarzyszem chorągwi husarskiej Jeremiego Wiśniowieckiego w 1651. Testament Jeremiego Wiśniowieckiego, s. 76. 17 XII 1648 szlachta krakowska na sejmiku przedkoronacyjnym wstawiła się za Szlichtyngiem, „który świeżo dwóch synów swych na usłudze R.P. pozbył”, Akta sejmikowe województwa krakowskiego, t. II, 1621-1648, wyd. A. Przy b oś, Kraków 1953, s. 375.

${ }_{93}$ Mariusz Stanisław Jaskólski (zm. 1683), strażnik wojskowy (już w 1648), pułkownik, kasztelan kijowski (1676), wojewoda czernihowski (1680), wojewoda podolski (1683), dyplomata (posłował m.in. kilkakrotnie na Krym w latach 1654-1656). Rotmistrz chorągwi kozackiej i wołoskiej, do niewoli dostał się pod Korsuniem. Został uwolniony po kilku dniach, razem z A.H. Sieniawskim, za okupem 300 talarów i zapewne za poręczeniem Mikołaja Potockiego, aby zgromadzić i dostarczyć Tuhaj bejowi pieniądze na wykupienie hetmana. Najpóźniej 5 czerwca był już w Barze. P. Kochan do NN, Bar 5 VI 1648. Документыл..., s. 37. APG 300, 29/129, k. 121; APG 300, R, Ee 32, s. 248; Michałowski, s. 35, 38; Szajnocha, s. 340, 342; Джерела..., t. I, s. 51, 73; Pamiętniki..., t. I, s. 287; Ojczyste spominki..., t. II, s. 17-18; T. Now ak, Jaskólski Mariusz Stanisław h. Leszczyc (zm.1683), PSB, t. XI, s. 63-66; A. Kerste n, Stefan Czarniecki..., s. 134.

${ }^{94}$ Ankwicz?

${ }^{95} \mathrm{~W}$ „Regestrze niewolników”: Terłecki (Terlecki).

${ }^{96}$ Być może Gąsiorowski, chorąży kwarcianej chorągwi kozackiej kasztelanica krakowskiego, starosty niżyńskiego Stefana Potockiego, syna hetmana w. kor., która brała udział w kampanii żółtowodzkiej, w tzw. grupie lądowej. „Likwidacyja wojsk”, k. 431v.

${ }^{97}$ Oraczewski, zapewne towarzysz chorągwi husarskiej starosty lwowskiego Adama Hieronima Sieniawskiego. „Likwidacyja wojsk”, k. 431v. Do niewoli dostał się pod Korsuniem. Pamiętniki..., t. I, s. 287; Niesiecki, t. VII, s. 124. Zygmunt Oraczewski podpisał elekcję Michała Korybuta w woj. krakowskim w 1669. Elektorowie..., s. 155. 


\section{Pani Wasilkowska z domu Strzemeska ${ }^{98}$}

P. Rosnowski ${ }^{99}$ W Dairze ${ }^{100}$

P. Stanisław Bobowski ${ }^{101}$

P. Osowski co trzyma Krasiłów od ${ }^{102}$

P. Mikołai Chirowoly tal. 300

P. Wacław Maliński ${ }^{103}$ tal. 200

P. Andrzej Obodinski ${ }^{104}$ tal. 1100

P. Franc[iszek] Białowski tal. 900

P. Jeziorkowski tal. 800

P. Bułdej tal. 500 u sołtanki pod Karasowem siedzi

P. Sarnawski tal. 2000

P. Swierski ${ }^{105}$ tal. 500

P. Drzewicki tal. 500

J.M.P. Sapieha ${ }^{106}$

98 Być może Jadwiga Wasilkowska, córka podsędka halickiego Krzysztofa Strzemeskiego. W niewoli tatarskiej miała się znajdować również jego matka i kuzynka Agnieszka. Niesiecki, t. VIII, s. 549; W. Ło zińs ki, Prawem i lewem. Obyczaje na Czerwonej Rusi w pierwszej połowie XVII wieku, Warszawa 2005 , s. 150 .

99 Chorąży roty kozackiej Jana Fryderyka Sapiehy, do niewoli dostał się pod Korsuniem, uwolniony przed 22 XI 1649. „Likwidacyja wojsk”, k. 431v; „Regestr kompaniej”.

${ }^{100}$ Dair - miejscowość w centralnej części Półwyspu Krymskiego, na północ od rzeki Sałgir (Salğır).

${ }_{101}$ W spisach urzędników podolskich (Urzędnicy podolscy..., s. 185; Urzędnicy województwa podolskiego XV-XVIII wieku (powiaty czerwonogradzki, kamieniecki, latyczowski). Spisy, opr. K. Pr z yb ós, Kraków 1994, s. 189) odnotowano informację o Stanisławie Bobowskim, któremu Boniecki błędnie przypisał urząd wojskiego latyczowskiego w 1668 r. W rzeczywistości w herbarzu figuruje nie Stanisław, lecz rotmistrz Jan Mikołaj Bobowski, który faktycznie pełnił ten urząd, ale w latach 1672-1684. Boniecki, t. I, s. 304; tak samo: Uruski, t. I, s. 247; M. Wa g n e r, Stownik biograficzny..., t. I, s. 23-24). Boniecki wymienia dwóch innych Stanisławów Bobowskich: pierwszego w ziemi czerskiej w 1646, drugiego: starostę owruckiego Stanisława Jana (1668). Stanisław Bobowski został odnotowany również w latach 1627-1629. Metryka Ruska..., s. 649, 653, 661. Według Uruskiego porucznik Stanisław Bobowski zginął w bitwie pod Chocimiem w 1673 r. Potwierdza to, nie podając jednak imienia, M. J e miołowski, Pamiętnik dzieje Polski w sobie zawierajacy (1618-1679), wyd. J. Dzięgielewski, Warszawa 2000, s. 418.

102 Zdanie niedokończone. Krasiłów należał wtedy do Władysława Dominika Ostrogskiego-Zasławskiego.

103 Malicki? Jeniec o takim nazwisku został wymieniony wśród wziętych do niewoli pod Kniażymi Bajrakami. Pamiętniki..., t. I, s. 283.

104 Zapewne Andrzej z Obodna Obodeńskiego z woj. bracławskiego (w 1641 i 1659). Руськa (Волинська) метрика..., s. 61, 70; R. Aft a n z z, Dzieje rezydencji na dawnych kresach Rzeczypospolitej, t. X., Województwo bracławskie, Wrocław 1996, s. 189-190.

105 Zapewne Jarosz Świerski (Świrski), sejmik przedsejmowy halicki 31 X 1650 zalecał w instrukcji swoim posłom na sejm, aby ,p. Jaros Swierski, iż w niewolej zostawał, a skarbowi winien, aby od tego uwolniony był długu". AGZ, t. XXIV, s. 87.

106 Jan Fryderyk Sapieha (1618-1664), po 1638 służył w armiach francuskiej i hiszpańskiej, od 1647 rotmistrz kwarcianej chorągwi kozackiej. Brał udział w kampanii żółtowodzkiej w tzw. grupie lądowej, kierował pracami fortyfikacyjnymi obozu nad Żółtymi Wodami, do niewoli dostał się 16 V 1648 pod Kniażymi Bajrakami, dowodząc wojskami koronnymi podczas odwrotu. Więziony w Dairze (przynajmniej do końca września 1648, potem w Perekopie), wykupiony został z niewoli (suma okupu 10 tys. 
P. Wituski ${ }^{107}$ tal. 500

P. Seweryn Sulima ${ }^{108}$ tal. 150

Andrzej Smierowicki tal. 200

P. Orzechowski ${ }^{109}$ tal. 250

P. Stanisław Witowski ${ }^{110}$ tal. 3000, atłasu karmazynowego łokci 6

Pan Felicjan Werescinski tal. 150

k. 181 [paginacja oryg. 3]

W Perekopie ci siedzą

P. Drzewicki staroście śniatyńskiemu służył

P. Karszicki ${ }^{111}$ wójta latyczowskiego syn

P. Mikołaj Stawski ${ }^{112}$

P. Janowski

P. Stoblowski J.M.P. Chomentowskiemu służył

P. Samuel Motowidło ${ }^{113}$

talarów) dopiero wiosną 1650. Diariusz z pierwszego okresu buntu..., s. 103-104; Raport pachołka..., s. 112-114; Kopia listu Koryckiego..., s. 29; List Jakuba Bełchackiego..., s. 90-92; APG 300, R, Ee 32, s. 259; APG 300, 29/129, k. 102v-103; Джерела..., t. I, s. 22, 28, 35, 63; Документы..., s. 32; Szajnocha, s. 323, 342; Michałowski, s. 26; Документыл..., s. 34-35; W. M aj е w s k i, Sapieha Jan Fryderyk $h$. Lis (1618-1664), PSB, t. XXXV, s. 1; W. Biernacki, op. cit., s. 101-102, 118-120; M. Nag i elski, Sytuacja jeńców..., s. 567; A. Ke rs sten, Stefan Czarniecki..., s. 129-134.

107 Jan Wituski, towarzysz chorągwi husarskiej Konstantego Lubomirskiego, „Zapłata Wojskom”, k. 7.

${ }_{108}$ Pułkownik kozacki w 1657 r., W. Li i iń s ki, op. cit., s. 564, 608-609. Na sejmie 1659 r. otrzymał dobra Kozary w woj. kijowskim. Руська (Волинська) метрика..., s. 162-163; Metryka Ruska ..., s. 768.

109 Wymieniony także w „Regestrze niewolników”.

${ }^{110}$ Wydaje się, że można wykluczyć, aby był to ówczesny kasztelan sandomierski Stanisław Witowski, uczestnik kampanii piławieckiej (wrzesień 1648), sejmów: konwokacyjnego (lipiec 1648), elekcyjnego (październik-listopad 1648), koronacyjnego (19 I-14 II 1649) i następnego po nim (22 XI 1649 - 12 I 1650). Relacje wojenne..., s. 130-131; A.S. Radziwiłł, op. cit., t. III, s. 98, 116; S. Ochmann-Staniszewska, Z. Staniszewski, op. cit., t. II, s. 333; J. Dąbrow ski, Senat koronny. Stan sejmujący w czasach Jana Kazimierza, Kraków 2000, s. 201, 209, 213; W. Kła c ze w s k i, Stanisław Witowski-żotnierz, dyplomata, polityk, „Res Historica”, t. XX, red. H. G mite rek, G. J awor, Lublin 2005, s. 91-95. Inny Stanisław Witowski, łowczy (łowczyc?) kijowski podpisał z woj. łęczyckim elekcję Michała Korybuta w 1669 r. Elektorzy..., s. 254; por. Urzędnicy województwa kijowskiego i czernihowskiego XV-XVIII wieku. Spisy, opr. E. J a n a s, W. Kł a c ze w s k i, Kórnik 2002, s. 34.

${ }^{111}$ Karśnicki (Karsznicki) h. Leliwa. Być może syn Jana Karśnickiego, który w 1629 r. odstąpił wójtostwo latyczowskie Bielskim. Boniecki, t. IX, s. 300.

112 Mógł to być jeden z dwóch znanych wówczas Mikołajów Stawskich: skarbnik przemyski w latach 1648-1653 (Urzędnicy województwa ruskiego..., s. 234, 392), zapewne elektor Władysława IV w r. 1632 (Elektorowie...., s. 215), który wziął udział w pospolitym ruszeniu szlachty przemyskiej 30 VII 1649 (AGZ, t. XXI, s. 58) lub podczaszy sanocki w 1652 r., stolnik sanocki w latach 1656-1679, chorąży latyczowski od 1679 r. (Urzędnicy województwa ruskiego..., s. 274, 297, 392; Urzędnicy podolscy..., s. 155, 233), który stawił się pospolite ruszenie ziemi chełmskiej i powiatu krasnostawskiego pod Chełmem 7 VIII 1649 (Akta sejmikowe ziemi chelmskiej 1572-1668, opr. W. Bondyra, H. Gmiterek, J. Ternes, Lublin 2013, s. 278).

${ }^{113}$ Samuel Motowidło (zm. 1673), w 1648 towarzysz chorągwi jazdy, wzięty do niewoli tatarskiej w bitwie pod Korsuniem, sprzedany do tureckiej marynarki wojennej, jako wioślarz na galerach spędził 18 lat. Wolność odzyskał po rozbiciu floty tureckiej przez kawalerów maltańskich (podczas wojny turecko-weneckiej), rzekomo podczas bitwy miało dojść do buntu wioślarzy i wybicia załogi galery. Po powrocie do kraju Motowidło od 1671 dowodził pułkiem Kozaków w służbie polskiej. Zginął 10 XI 


\section{P. Adam Gliński ${ }^{144}$ \\ P. Wilczkowski ${ }^{115}$ \\ P. Remigian Choiński ${ }^{116}$ \\ P. Christoff Seredrowski \\ P. Wincent[y] Przerębski ${ }^{117}$ u Bertesa Murzy \\ P. Stefan Stapkowski ${ }^{118}$ w Karasowie}

1673 w czasie walk z Turkami pod Chocimiem. W. Majewski, Motowidto Jan [sic!] h. Prus (zm. 1673). PSB, t. XXII, s. 152-153; M. Wa gn er, Stownik biograficzny ..., t. I, s. 196-197.

114 Adam Gliński h. Pókozic (zm. po 1682) z Zimnej Wody w pow. pilzneńskim, wojski sandomierski (1658-1661), podstoli sandomierski (1661-1663), burgrabia krakowski (1663-1665), stolnik sandomierski (1665-1676), chorąży sandomierski (1676-1680), elektor Michała Korybuta z woj. sandomierskiego w 1669 r. Porucznik jazdy, służbę zaczynał ok. 1648 r. jako towarzysz. N i e s i e cki, t. IV, s. 137-140; U ruski, t. IV, s. 181; B oni e ck i, t. VI, s. 77; M. Wagner, Stownik biograficzny..., t. I, s. 98-99; Urzędnicy województwa sandomierskiego XVI-XVIII wieku, opr. K. Chłap ow ski, A. F a lniowska-Gradowska, Kórnik 1993, s. 86, 110, 120, 128, 179; Elektorowie..., s. 55.

115 Być może Władysław Wilczkowski h. Jelita, porucznik chorągwi husarskiej wojewody sandomierskiego Władysława Myszkowskiego (już 1653), porucznik chorągwi husarski Aleksandra Lubomirskiego (1661), pułkownik i regimentarz wojska koronnego w 1661 i 1668 r., starosta żwinogrodzki i wiski, rzekomy cześnik chełmski (od 1655). M. J e mi oło w s ki, op. cit., s. 582; M. Wa g n e r, Korpus oficerski wojska polskiego w drugiej pot. XVII w., Oświęcim 2015, według indeksu; E. J a n a s, op. cit., s. 24, 42, 44, 47-53; Urzędnicy województwa betskiego i ziemi chetmskiej XIV-XVIII wieku. Spisy, opr. H. Gmiterek, R. Szczy gieł, Kórnik 1992, s. 150, 274.

116 Remigian Franciszek Choiński na Andrzejowie (zm. przed 14 VI 1701), skarbnik chełmski od 1659 r., komornik ziemski chełmski w 1673 r. (Urzędnicy województwa sandomierskiego..., s. 186, 222) elektor Michała Korybuta z woj. chełmskiego w 1669 r. (Elektorowie..., s. 28). Wziął udział w popisie pospolitego ruszenia ziemi chełmskiej i powiatu krasnostawskiego pod Chełmem 7 VIII 1649. Akta sejmikowe ziemi chetmskiej..., s. 279; Niesiecki, t. III, s. 70. W 1651 ze szlachtą krakowską wyruszył pod Beresteczko w 1651 r., ale w bitwie nie uczestniczył, gdyż 26 czerwca ,szlachta województwa krakowskiego [...] wróciła do województwa dla uśmierzenia chłopskiej rebelii [Aleksandra Kostki Napierskiego]". Materiały do powstania Kostki Napierskiego 1651 r., wyd. A. Przy b ós, Wrocław 1951, s. 42.

117 Wincenty Przerębski służył w armii koronnej już na początku lat trzydziestych, był jednym z posłów „żołnierzy z Podola” na sejmie konwokacyjnym w 1632 r., jako porucznik chorągwi hetmana w. kor. Stanisława Koniecpolskiego walczył z Kozakami w latach 1637-1638 („w obie ręce ranny i w kolano" pod Kumejkami 16 XII 1637), członek komisji królewskiej wprowadzającej ordynację kozacką na Masłowym Stawie 4 XII 1638. Podpisał elekcję Władysława IV i Michała Korybuta z woj. sieradzkim, A.S. Radziwiłł, op. cit., t. I, s. 123; Korespondencja Stanisława Koniecpolskiego..., s. 444-445; S. Okolski, Dyaryusz transkacyi wojennej między wojskiem koronnem i zaporoskiem w r. 1637, wyd. K.J. Turow ski, Kraków 1858, s. 3, 57; S. Oświę ci m, Dyaryusz 1643-1651, wyd. W. Czermak, Kraków 1907, s. 61; S. O kols k i, Kontynuacyja dyaryusza wojennego czułościa Jaśnie Wielmożnych Ich Mciów Panów Hetmanów Koronnych, cnota cnego rycerstwa polskiego nad zawiętymi w uporze krzywoprzysieglych i swowolnych Kozakami w roku 1638 odprawiona ..., wyd. K.J. Tu ro ws ki, Kraków 1858, s. 192; A. B orowi a k, op. cit., s. 155; Elektorowie..., s. 179. Do niewoli dostał się nad Żółtymi Wodami (Niesiecki, t. VII, s. 543), według mylnych informacji miał zostać uwolniony już na początku czerwca 1648 (Pesławski do NN, Połonne 3 VI 1648. Джерела..., t. I, s. 43), ale jego pobyt w niewoli potwierdza relacja Łukasza Miaskowskiego z 7 VII 1648. Ibidem, s. 88.

118 Brat rotmistrza jazdy koronnej Krzysztofa Stapkowskiego. Stefan Stapkowski w 1650 był towarzyszem chorągwi husarskiej woj. krakowskiego Władysława Myszkowskiego, potem porucznikiem chorągwi kozackiej Myszkowskiego. W styczniu 1656 podpisał konfederację w Lańcucie, w kwietniu tegoż roku zginął w walkach za Szwedami pod Kozienicami. AGAD, ASW dz. 86, nr 38, k. 4v; M. J e mi oło w s ki, op. cit., s. 192; M. N a gi e l s k i, Stapkowski Krzysztof, PSB, t. XLII, s. 271. 
P. Szymbrowski

P. Wydżga syn pana podczaszego lwowskiego ${ }^{119}$

W Kaffie siedzą

P. Timińskich ${ }^{120} 3$.

P. Lugewnicki ${ }^{121}$

P. Trzeciecki

Co w Kirci ${ }^{122}$ siedzą pod Kaffą

P. Gliński ${ }^{123}$

P. Nowosielski

P. Leski

P. Branicki

P. Jan Markowski

P. Brucki ${ }^{124}$

P. Spilanski ${ }^{125}$

P. Franc[iszek] Kobyłecki ${ }^{126}$

P. Golecki

P. Adam Chrząstowski ${ }^{127}$

P. Kolaczkowski

P. Bieławski

119 Prawdopodobnie pomyłka. Podczaszym lwowskim był wówczas Andrzej Stano. Urzędnicy województwa ruskiego..., s. 129. Wymieniony jeniec mógł być synem Jana Wydżgi, podsędka lwowskiego (1640-1651). Ibidem, s. 137, 406.

${ }^{120}$ Jeden z nich to zapewne towarzysz chorągwi husarskiej starosty krakowskiego Jerzego Lubomirskiego, który jako ochotnik brał udział w kampanii żółtowodzkiej w grupie lądowej, Bełchacki wymienia go w grupie jeńców wziętych pod Kniażymi Bajrakami. List Jakuba Bełchackiego..., s. 91-92. Zapewne inny Tymiński dostał się do niewoli pod Korsuniem. Pamiętniki..., t. I, s. 287. Jednego z Tymińskich wykupił w Jassach Milicz, „Regestr niewolników”. S.Z. D r u s z k i e w i c z, op. cit., s. 89.

${ }^{121}$ Być może Łagiewnicki, towarzysz chorągwi kozackiej Piotra Komorowskiego. „Likwidacyja wojsk", k. 431v.

${ }^{122}$ Być może Kercz należący wówczas do ejaletu Kaffy.

${ }^{123}$ Być może Aleksander Gliński, brat Adama, towarzysz i chorąży jazdy koronnej w latach 1656-1657. M. Wag ne r, Stownik biograficzny..., t. I, s. 98-99.

${ }_{124}$ Brzuski? „Regestr niewolników” wymienia Walera Brzuskiego.

${ }^{125}$ Szpaliński, towarzysz chorągwi kozackiej starosty kamienieckiego Piotra Potockiego. „Likwidacyja wojsk", k. 431v.

${ }^{126}$ Franciszek Kobyłecki h. Godziemba (ok. 1625 - ok. 1682), podczaszy mielnicki od 1661 r., sędzia wojskowy (przed 1670), podczas wojny ze Szwecją w latach 1655-1660 w dywizji Stefana Czarnieckiego, poseł do Krymu i Turcji w latach 1664-1674, jako rotmistrz chorągwi kozackiej walczył na Ukrainie w 1671, pod Niemirowem w 1672 i Chocimiem w 1673 r. Jeden z głównych działaczy związku wojskowego pod Szczebrzeszynem w 1672, jako marszałek koła wojskowego reprezentował żołnierzy na komisji wojskowej w 1674, A. Kersten, Kobytecki Franciszek h. Godziemba (ok. 1625 - ok. 1682), PSB, t. XIII, s. 173-174; M. Wag ner, Stownik biograficzny..., t. II, s. 133-135; idem, Korpus oficerski..., według indeksu.

127 Zapewne Adam Chrząstowski z Brzezia, w latach 1662-1676 właściciel wsi Bartkówka w ziemi sanockiej, w 1669 r. elektor Michała Korybuta z woj. Krakowskiego. Polska poludniowo-wschodnia w epoce nowożytnej. Źródta dziejowe, t. II, cz. 2, Rejestr poborowy ziemi sanockiej z 1655, wyd. Z. B udzyńs ki, K. Przyboś, Rzeszów 1998, s. 25; Elektorowie..., s. 30. 
P. Samuel Prusiński ${ }^{128}$

[k. 181v oryginalna $3 \mathrm{v}$ ]

Pod Kaffą siedzą u Siefer Murzy

P. Zachariasz Bielecki ${ }^{129}$

P. Racinski

Krzystof Swerczewski

Co mam to posyłam, zostając sługą W.M.M.M. Pana

Oszinski

\section{BIBLIOGRAFIA}

\section{Źródła rękopiśmienne}

Archiwum Główne Akt Dawnych w Warszawie, Akta Skarbowo-Wojskowe, dz. 86, nr 38, $39,40$.

Archiwum Państwowe w Gdańsku: 300, 29/129; 300, 29/133; 300, 53/101; 300, R/Ee 32.

Biblioteka Uniwersytetu Wrocławskiego, rkps akc. 1949/440, Polonica, Varia, t. III.

Geheimes Staatsarchiv Preussischer Kulturbesitz Berlin-Dahlem, XX Hauptabteilung, Etats Ministerium 111h, nr 152.

\section{Źródła drukowane}

Akta grodzkie i ziemskie z czasów Rzeczypospolitej Polskiej z archiwum tak zwanego bernardyńskiego we Lwowie, t. XXI, Lauda sejmikowe, t. II, Lauda wiszeńskie 1648-1673, wyd. A. Prohaska, Lwów 1911.

Akta grodzkie i ziemskie z Archiwum Ziemskiego we Lwowie, t. XXIV, Lauda sejmikowe halickie 1575-1695, wyd. A. Pro has ka, Lwów 1931.

Akta sejmikowe województwa krakowskiego, t. II, 1621-1648, wyd. A. Przyboś, Kraków 1953.

Akta sejmikowe ziemi chetmskiej 1572-1668, opr. W. Bondyra, H. Gmiterek, J. Tern e s, Lublin 2013.

Документы об освободительной войне украинского народа 1648-1654 г2, Киев 1965.

Druszki e w i c z S.Z., Pamiętniki 1648-1697, wyd. M. Wagne r, Siedlce 2001.

Джерела з історіі Національно-визвольної війни українського народу 1648-1658 pp., t. I-II , упор. Ю. М иц и к, Київ 2012-2013.

Hadży Mehmed Senai, Historia chana Islama Gereja III, wyd. Z. A bra hamow ic z, Warszawa 1971.

Jakuba Michałowskiego, wojskiego lubelskiego a później kasztelana bieckiego księga pamiętnicza, wyd. A.Z. Helc el, Kraków 1864.

128 Być może Samuel Pruszyński (Prusiński) h. Rawicz, elektor Władysława IV z woj. lubelskiego. Elektorowie..., s. 178; Ni es i e cki, t. VII, s. 527.

129 Zapewne chorąży chorągwi kozackiej Mikołaja Zaćwilichowskiego., „Likwidacyja wojsk”, k. 431v. 
Jemiołowski M., Pamiętnik dzieje Polski w sobie zawierający (1618-1679), wyd. J. Dzi zęg i el ew ski, Warszawa 2000.

Ko chow sk i W., Historia panowania Jana Kazimierza, t. I, wyd. E. Ra c zy ń s ki, Poznań 1859.

Korespondencja Stanisława Koniecpolskiego, hetmana wielkiego koronnego, opr. A. B i edr zy ck a, Kraków 2005.

Materiały do powstania Kostki Napierskiego 1651 r., wyd. A. Przy b oś, Wrocław 1951.

Metryka Ruska (Wotyńska). Regesty dokumentów z kancelarii koronnej dla ziem ukraińskich (województw wołyńskiego, bracławskiego, kijowskiego i czernihowskiego) 1569-1673, Kijów 2002.

Ojczyste spominki w pismach do dziejów dawnej Polski. Diaryusze, relacje, pamiętniki, wyd. A. Grabowski, t. II, Kraków 1845.

Okolski S., Dyaryusz transkacyi wojennej między wojskiem koronnem i zaporoskiem wr. 1637, wyd. K.J. Turow ski, Kraków 1858.

Okolski S., Kontynuacyja dyaryusza wojennego czułościa Jaśnie Wielmożnych Ich Mciów Panów Hetmanów Koronnych, cnota cnego rycerstwa polskiego nad zawiętymi w uporze krzywoprzysieglych i swowolnych Kozakami w roku 1638 odprawiona, wyd. K.J. Turows ki, Kraków 1858.

Ośw ięcim S., Dyaryusz 1643-1651, wyd. W. Czermak, Kraków 1907.

Pamiętniki do panowania Zygmunta III, Władysława IV i Jana Kazimierza, wyd. K.W. W ó j c i cki, Warszawa 1846.

Płaca pocztom panięcym w r. 1650, wyd. A. S a w c zy ń s ki, Przegląd Historyczno-Wojskowy, t. IX, 1937, s. 119-125.

Polska południowo-wschodnia w epoce nowożytnej. Źródta dziejowe, t. II, cz. 2: Rejestr poborowy ziemi sanockiej z 1655, wyd. Z. Budzyń s ki, K. Przyboś, Rzeszów 1998.

Radziwiłł A.S., Pamiętnik o dziejach w Polsce, t. III: 1647-1656, wyd. A. Przyboś, R. Że lew ski, Warszawa 1980.

Relacje wojenne z pierwszych lat walk polsko kozackich powstania Chmielnickiego okresu „Ogniem i mieczem” (1648-1651), wyd. M. Na gi e ls k i, Warszawa 1999.

Руська (Волинська) метрика. Книга за 1652-1673 рp., уклад. П. Кулаковський, Острог-Варшава-Москва 1999.

S zaj n o ch a K., Dwa lata dziejów naszych 1646. 1648. Opowiadanie i źródta, t. II: Polska w 1648, Lwów 1869.

Testament Jeremiego Wiśniowieckiego, wyd. W. To m ki ew ic z, „Miesięcznik Heraldyczny" 1930, R. IX, nr 4, s. 67-77.

Volumina legum, t. IV, Petersburg 1860.

Жерела до істориї України Руси, t. IV, Материяли до істориї Галичини, зіб. С. Том аш і в с ь ки й, t. I, Львӥв 1898.

Жерела до істориї України Руси, t. XII, Матеріяли до історії української Козаччини, т. V: Акти до Хмелниччинии (1648-1657), вид. М. Корду ба, Львӥв 1911.

\section{Opracowania}

A ugus i ewicz S., Gabriel Woynitłowicz, oficer jazdy koronnej z pot. XVII w.. Zarys Biografii, „Studia z Dziejów Wojskowości” 2012, t. I, s. 101-127.

Aftan azy R., Dzieje rezydencji na dawnych kresach Rzeczypospolitej, t. X: Województwo bractawskie, Wrocław 1996. 
Baranowski B., Dzieje jasyru na Gródku Karaimskim, „Myśl Karaimska” 1946-1947, R. XXIV, Seria Nowa, t. II, s. 40-52.

B a r a n o w s k i B., Ormianie w stużbie dyplomatycznej Rzeczypospolitej, „Myśl Karaimska” 1946, R. XXIII, Seria Nowa, t. 1, s. 130.

B ierna cki W., Żółte Wody - Korsuń 1648, Warszawa 2004.

B orowiak A., Powstanie kozackie 1638, Zabrze 2010.

Części ik Ł., Sejm warszawski w 1649/1650 roku, Wrocław 1978.

D ą b row s k i J., Senat koronny. Stan sejmujacy w czasach Jana Kazimierza, Kraków 2000.

Elektorowie królów Władystawa IV, Michała Korybuta, Stanisława Leszczyńskiego i spis stronników Augusta III, opr. J. D un in-B ork ow s ki, M. D u n in - W ą s o w i c z, „Rocznik Towarzystwa Heraldycznego we Lwowie” 1908/1909, t. I.

Gaw ę d a M., Powstanie kozackie 1637, Zabrze 2007.

J a n s E., Konfederacja wojska koronnego w latach 1661-1663, Lublin 1998.

Kersten A., Stefan Czarniecki 1599-1665, Warszawa 1963.

Kłaczewski W., Stanisław Witowski - żotnierz, dyplomata, polityk, „Res Historica”, t. XX, red. H. Gmitere k, G. J aw or, Lublin 2005, s. 91-100.

Krząstek T., Majewski W., Nagielski M., Storożenko I.S., Żótte Wody-1648, Warszawa 1999.

K u p is z D., Wojska powiatowe samorzadów Matopolski i Rusi czerwonej w latach 15721717, Lublin 2008.

Łoziński W., Prawem i lewem. Obyczaje na Czerwonej Rusi w pierwszej połowie XVII wieku, Warszawa 2005.

Majewski W., Krytyczny przegląd źródet do dziejów powstania Chmielnickiego w okresie początkowym (jesień 1657 - maj 1648), „Studia Źródłoznawcze” 1981, t. XXVI, s. $141-162$.

Milewski D., Rywalizacja polsko-kozacka o Mołdawie $w$ dobie powstania Bohdana Chmielnickiego (1648-1653), Zabrze 2011.

Nagi els ki M., Choragwie dworzańskie Jana Kazimierza podczas dwóch batalii kozackich 1649-1651 [w:] Gospodarka, ludzie władza. Studia historyczne ofiarowane Juliuszowi Łukasiewiczowi w 75. rocznicę urodzin, red. M. Ko p c zy ńs ki, A. Mą c zak, Warszawa 1998, s. 115-128.

Nagi elski M., Sytuacja jeńców w początkowym okresie powstania Chmielnickiego w latach 1648-1652, „Przegląd Historyczny” 2014, t. CV, z. 4, s. 565-584.

$\mathrm{Nag}$ i l ls ki M., Z dziejów jasyru polskiego w Bachczysaraju w połowie XVII w. Przyczynek do działalności dyplomaty i tlumacza języków orientalnych Romaszkiewicza w stużbie Rzeczypospolitej [w:] Polacy na poludniowej Ukrainie, red. T. Ci es i els ki, W. Ku s zn ir, Odessa-Opole-Olsztyn 2006, s. 53-63.

Ochmann-Stan is zew ska S., S tan is zew ski Z., Sejm Rzeczypospolitej za panowania Jana Kazimierza Wazy. Prawo - doktryna - praktyka, t. I-II, Wrocław 2000.

Polski Słownik Biograficzny, t. I-LI, Kraków 1935-2016.

Rogowicz M., Skład sit polskich nad Żółtymi Wodami i pod Korsuniem w 1648 roku, „Przegląd Historyczno-Wojskowy” 2015, t. XIV, z. 2, s. 39-62.

Rolle A., Zdrada kamieniecka [w:] Opowiadania historyczne, seria VII, Lwów 1891.

S e r c zy k W.A., Na płonacej Ukrainie. Dzieje Kozaczyzny 1648-1651, Warszawa 1998.

Urzędnicy podolscy XIV-XVIII w., opr. E. Janas, W. Kłaczewski, J. Kurtyka, A. S o c ha ck a, Kórnik 1998.

Urzędnicy województwa betskiego $i$ ziemi chetmskiej XIV-XVIII wieku. Spisy, opr. H. Gmiterek, R. S zc zy gi eł, Kórnik 1992. 
Urzędnicy województwa kijowskiego $i$ czernihowskiego XV-XVIII wieku. Spisy, opr. E. J a n as, W. Kła c zew s ki, Kórnik 2002.

Urzędnicy województwa podolskiego XV-XVIII wieku (powiaty czerwonogradzki, kamieniecki, latyczowski). Spisy, opr. K. Pr zy b oś, Kraków 1994.

Urzędnicy województwa ruskiego XIV-XVIII wieku (Ziemie halicka, lwowska, przemyska, sanocka), opr. K. Przy b oś, Wrocław 1987.

Urzędnicy województwa sandomierskiego XVI-XVIII wieku, opr. K. Chłapowski, A. Falniowska-Gradowska, Kórnik 1993.

Wa g n er M., Korpus oficerski wojska polskiego w drugiej poł. XVII w., Oświęcim 2015.

Wagner M., Stownik biograficzny oficerów polskich drugiej połowy XVII wieku, t. I-II, Oświęcim 2013-2014.

Wag n e r M., Wykup jeńców z niewoli tureckiej i tatarskiej w końcu XVII wieku, Українська Орієнталістика, Випуск 6, Київ 2012, s. 29-35.

Wimmer J., Materiały do zagadnienia organizacji i liczebności armii koronnej $w$ latach 1648-1655, „Studia i Materiały do Historii Wojskowości”, t. V, Warszawa 1960, s. $477-509$.

Z dziejów Ukrainy. Księga pamiątkowa ku czci Włodzimierza Antonowicza, Paulina Święcickiego i Tadeusza Rylskiego, red. W. Li pińs ki, Kijów 1912. 